\title{
Self-Dealing by Controlling Shareholders: Improving Minority Protection in Light of Article 9c SRD
}

\author{
by
}

Nick Hallemeesch*

Controlling shareholders may cause a company to enter into transactions with themselves or one of their subsidiaries, thereby expropriating minority shareholders. General principles of company law, such as board autonomy, often do not adequately constrain controlling shareholders. Moreover, Belgian, French and Dutch courts apply deferential standards of review to related party transactions, while approval procedures in these jurisdictions are also flawed. A recent amendment to the Shareholder Rights Directive requires adequate protection of minority shareholders against self-dealing. Member States may subject related party transactions to a majority-of-minority vote, the approval of independent directors or judicial review. This paper discusses the efficiency of each of these mechanisms.

Table of Contents

ECFR 2018, 197-235

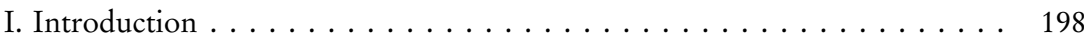

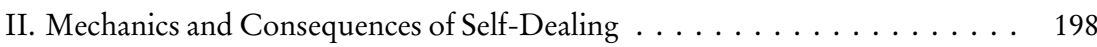

III. Are General Principles of Company Law Helpful? . . . . . . . . . . . . 204

A. Board Autonomy . . . . . . . . . . . . . . . . . . . . . . . . . . . . 204

B. Equal Treatment of Shareholders . . . . . . . . . . . . . . . . . . . 209

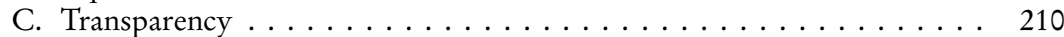

IV. Inadequacy of Self-Dealing Mechanisms in Some Civil Law Jurisdictions .. 212

A. Voting on Conflicted Transactions . . . . . . . . . . . . . . . 212

B. Deferential Standards of Review . . . . . . . . . . . . . . . . . . . 213

C. Unsatisfactory Approval Procedures . . . . . . . . . . . . . . . . 222

D. Conclusion: Need for Improvement . . . . . . . . . . . . . . . . . . . . . 224

V. Overview of Article 9c Shareholders' Rights Directive . . . . . . . . 225

* Ph.D. Candidate, University of Leuven; LL.M., Harvard Law School. This research was funded by the Belgian American Educational Foundation and the Harvard Law School Summer Academic Scholarship. I wish to thank Prof. Bernard Tilleman and Mr. Jarret Huang for their useful comments. All mistakes are mine. A related article on this topic has been published in Dutch: N. Hallemeesch, 'Belangenconflicten van meerderheidsaandeelhouders. Zoektocht naar betere minderheidsbescherming vanuit rechtseconomisch en rechtsvergelijkend perspectief' (2017) TRV-RPS 5-41. 
VI. Efficiency of Self-Dealing Mechanisms _ . . . . . . . . . . . . . . . 226

A. Judicial Review or Approval Procedure? . . . . . . . . . . . . . . . . 226

B. Shareholders or Directors? . . . . . . . . . . . . . . . . . 230

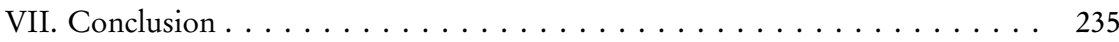

\section{Introduction}

1. This paper aims at making a contribution to the quest for adequate minority protection against related party transactions in listed companies. Considering the dominance of concentrated ownership structures in continental Europe, this paper is confined to self-dealing by controlling shareholders. The first chapter of this paper discusses the mechanics and consequences of self-dealing. The second chapter discusses why general principles of company law, which are often deemed the first line of defence in protecting minority shareholders, do not adequately constrain controlling shareholders. The third chapter describes the current legal regime in Belgium, France and the Netherlands. It is explained how traditional legal strategies against self-dealing are designed and applied in these jurisdictions, and why they do not offer adequate protection to minority shareholders. The fourth chapter discusses the recent amendment to the Shareholders' Rights Directive, which requires adequate protection of minority shareholders against related party transactions. Member States may subject related party transaction to a majority-of-minority vote, the approval of independent directors or, sometimes, judicial review. The fifth chapter suggests how Member States should choose between each of these mechanisms, by discussing their comparative efficiency.

\section{Mechanics and Consequences of Self-Dealing}

2. Risk of value diversion by controlling shareholder imposes a cost on the company - Market forces stimulate managers and shareholders to increase share value. ${ }^{1}$ However, markets are never fully competitive. ${ }^{2}$ In widely held companies, the market for corporate control creates an additional check on

1 R.K. Winter, 'State Law, Shareholder Protection, and the Theory of the Corporation' (1977) 6 JLS 251, 264.

2 K. Kastiel, 'Executive Compensation in Controlled Companies' (2015) 90 Ind.L.J. 1131, 1139; M.J. Roe, 'The Institutions of Corporate Governance' in C. Ménard and M. M. Shirley (eds), Handbook of New Institutional Economics (Springer, Dordrecht 2005) 378; R.K. Winter, 'State Law, Shareholder Protection, and the Theory of the Corporation’ (1977) 6 JLS 251, 266. 
managers. ${ }^{3}$ If outsiders can acquire control through a hostile takeover bid, management is subject to the threat of removal if share value drops. ${ }^{4}$ Similarly, unsatisfied shareholders may engage in a proxy fight to replace the board. Controlling shareholders, however, cannot be replaced. As their control is not contestable, the threat of hostile takeovers and control contests do not incentivize controlling shareholders to maximize share value. ${ }^{5}$ Instead of maximizing share value, a controlling shareholder may improve his personal wealth at the expense of the company ('tunnelling'). ${ }^{6}$

One of the main channels to divert firm value is self-dealing. ${ }^{7}$ A controlling shareholder thereby causes a company to enter into transactions with himself or one of his (other) subsidiaries - hereafter both referred to as 'related party'. Indeed, the controller has a decisive influence at both sides of the transaction and thus unilaterally decides on the terms and conditions. This is often also the case when qualified majorities apply to the decision, considering the collective action problem among minority shareholders (infra, no 23). A controlling shareholder is induced to disfavour the listed company or its subsidiary and favour himself or the subsidiary in which he holds a greater amount of cashflow rights. The value that moves between two companies is partially captured by the controlling shareholder. These private benefits mean that firm value declines and that outside minority investors are partially expropriated of their cash-flow rights.

3 L.A. Bebchuk, 'The Case Against Board Veto in Corporate Takeovers' (2002) 69 U.Chi. L.Rev. 973, 997; F.H. Easterbrook and D.R. Fischel, 'The Proper Role of a Target's Management in Responding to a Tender Offer' (1981) 94 Harv.L.Rev. 1161, 1174.

4 H. Manne, 'Mergers and the Market for Corporate Control' (1965) 73 J.Pol.Econ. 110, 112-113.

5 L.A. Bebchuk and A. Hamdani, 'The Elusive Quest for Global Governance Standards' (2009) 157 U.Pa.L.Rev. 1263, 1285-1288.

6 L.A. Bebchuk, 'A Rent-Protection Theory of Corporate Ownership and Control' (1999) NBER Working Paper 7203.

7 Other channels for tunnelling are discussed in L. Enriques, 'Related Party Transactions: Policy Options and Real-World Challenges (with a Critique of the European Commission Proposal) (2015) 16 EBOR 1, 10-11.

8 P.H. Conac, L. Enriques and M. Gelter, 'Constraining Dominant Shareholders' SelfDealing: The Legal Framework in France, Germany, and Italy’ (2007) 4 ECFR 491, 495; R.J. Gilson and J.N. Gordon, 'Controlling Shareholders' (2003) 152 U.Pa.L.Rev. 784, 787; S. Johnson, R. La Porta, F. Lopez-de-Silanes and A. Schleifer, 'Tunneling' (2000) 90 Am.Ec.Rev. 22. 'Subsidiary' is used to refer to all legal entities which are either directly or indirectly controlled by a parent, here the controlling shareholder.

9 S. Djankov, R. La Porta, F. Lopez-de-Silanes and A. Schleifer, 'The law and economics of self-dealing' (2008) 88 J.Fin.Econ. 430, 430. 
Several types of related party transactions should be considered. ${ }^{10}$ First, controlling shareholders can sell goods or services to the company or make the company buy goods and services from them. This type of self-dealing is extremely varied: supply of commodities, financial assistance, secondment of staff, shared publicity campaigns, etc. Second, controlling shareholders can initiate parent-subsidiary mergers. If a parent (controlling shareholder) directly or indirectly absorbs a subsidiary (listed company), the parent pays a price to the outside investors of the listed company. By undervaluing the shares of the acquired company, a controlling shareholder promptly - and maybe substantially - expropriates minority shareholders through a one-shot transaction.

3. If company law is poor, some companies cannot go public or raise additional capital - The risk of expropriation ex post means that outside investors require a discount on their investment ex ante. ${ }^{11}$ The conflict of interests between a controlling shareholder and outside investors thus imposes a cost on the company, because it decreases the price of its shares and increases the cost of capital. ${ }^{12}$ Good company law helps companies to reduce agency cost. ${ }^{13}$ Outside investors have less reason to fear controlling shareholders if company law protects them against value diversion by corporate insiders. ${ }^{14}$ The quality of company law, particularly in the realm of self-dealing, thus drives two kinds of decisions.

First, the quality of corporate governance partly drives the decisions of companies whether or not to go public. ${ }^{15}$ Going public entails a cost of increased

10 Conac et al. consider only business transactions as 'related party transactions', but not the corporate transactions: P.H. Conac, L. Enriques and M. Gelter, 'Constraining Dominant Shareholders' Self-Dealing: The Legal Framework in France, Germany, and Italy' (2007) 4 ECFR 491, 496.

11 P.L. Davies and S. Worthington, Gowers' Principles of Modern Corporate Law (10th ed. Sweet \& Maxwell 2016) 631-632; J.E. Fisch, 'Measuring Efficiency in Corporate Law: the Role of Shareholder Primacy’ (2006) J.Corp.L 637, 656-657; R. Clark, Corporate law (Little, Brown and Company, Boston 1986) 156-157; H. Demsetz and K. Lehn, 'The Structure of Corporate Ownership' (1985) 93 J.Pol.Econ. 1155, 1158.

12 F.H. Easterbrook and D.R. Fischel, The Economic Structure of Corporate Law (Harvard University Press 1991) 96.

13 L.A. Bebchuk, R. Kraakman and G. Triantis, 'Stock Pyramids, Cross-Ownership, and Dual Class Equity' (2000) Harvard Law School Olin Discussion Paper 249, 14-15.

14 M.J. Roe, Political Determinants of Corporate Governance (Oxford University Press, 2003) 164 .

15 L.A. Bebchuk, 'A Rent-Protection Theory of Corporate Ownership and Control' (1999) NBER Working Paper 7203, 24. This view is consistent with empirical findings that the level of investor protection correlates positively with stock market development: S. Djankov, R. La Porta, F. Lopez-de-Silanes and A. Schleifer, 'The law and economics of self-dealing' (2008) 88 J.Fin.Econ. 430; R. La Porta, F. Lopez-de-Silanes 
compliance and more complex monitoring. On the other hand, access to public capital markets allows a company to expand and capture new markets, acquire another company, or finance the development of new products. A larger company may be more efficient because of economies of scale and professionalization of management. ${ }^{16}$ If efficiency gains offset listing cost, a company may want to go public. However, if company law does not constrain controlling shareholders, outside investors are less inclined to buy shares and the price of capital is high. Poor company law thus prevents some companies from going public and prevents some public companies from raising additional capital. These financing constraints hamper a company's ability to pursue efficiency gains.

Of course, companies do not live by the law alone. ${ }^{17}$ Capital markets are reputational markets: if controlling shareholders (or directors) treat minority shareholders unfairly, the price of shares will decrease and their company will face a higher cost of capital. ${ }^{18}$ While reputation unarguably has a positive impact on corporate governance ${ }^{19}$, it does not always constrain controlling shareholders. ${ }^{20}$ First, initial public offerings bear the risk of being adversely selected: since investors do not know which type of controlling shareholder they are dealing with, honest controllers are driven out of the market even before reputational markets come into being. ${ }^{21}$ Second, reputation is not a proxy for future intentions. A controlling shareholder may sell control to a third party, or may be taken over by a third party himself. Both situations cause an alteration of firm strategy. Mandatory bid rules may ease the fear of

and A. Schleifer, 'Law and Finance' (1998) 106 J.Pol.Econ. 1113. This view is also consistent with empirical findings that the level of private benefits of control correlates negatively with stock market development: A. Dyck and L. Zingales, 'Private Benefits of Control: An International Comparison' (2004) 59 J.Fin. 537.

16 A.D. Chandler, Scale and scope: the dynamics of industrial capitalism (Harvard University Press, Cambridge 1990).

17 R.K. Winter, 'State Law, Shareholder Protection, and the Theory of the Corporation' (1977) 6 JLS 251, 262.

18 M.J. Roe, 'The Institutions of Corporate Governance' in C. Ménard and M.M. Shirley (eds), Handbook of New Institutional Economics (Springer, Dordrecht 2005) 378-379.

19 R. Cheffins, 'Law as Bedrock: The Foundations of an Economy Dominated by Widely Held Public Companies' (2003) 23 OJLS 1, 14. See on the role of reputation in the development of financial markets in Japan and China: Y. Miwa and J.M. Ramseyer, 'The Value of Prominent Directors: Corporate Governance and Bank Access in Transitional Japan' (2002) 31 JLS 273; F. Allen, J. Qian, M. Qian, 'Law, finance and economic growth in China' (2005) 77 J.Fin.Econ. 57.

20 S. Djankov, R. La Porta, F. Lopez-de-Silanes and A. Schleifer, 'The law and economics of self-dealing' (2008) 88 J.Fin.Econ. 430, 431.

21 Z. Goshen, 'The Efficiency of Controlling Corporate Self-Dealing: Theory Meets Reality' (2003) 91 Cal.L.Rev. 393, 404-407; B. Black and R. Kraakman, 'A Self-Enforcing Model of Corporate Law' (1996) 109 Harv.L.Rev. 1912, 1923. 
outside investors, but do so imperfectly. ${ }^{22}$ Hence, outside investors require a discount on their investment, regardless of the controlling shareholder's intentions or reputation. The absence of agency cost ex post does not preclude financing constraints and thus agency cost ex ante.

\section{If company law is poor, some controlling shareholders cannot surrender} control - Second, the quality of corporate governance partly drives the decisions of controlling shareholders whether or not to surrender control. ${ }^{23}$ Control over a public company entails a high cost of lost liquidity and portfolio diversification..$^{24}$ Moreover, managing the company requires the controller to expend resources. On the other hand, a controlling shareholder may increase share value to a larger extent than managers in a widely held company would do. ${ }^{25}$ However, if the cost of control exceeds the benefits that a shareholder derives from it, he may want to relinquish control. ${ }^{26}$ If company law then does not constrain controlling shareholders, selling control to the public leaves private benefits of control up for grabs. ${ }^{27} \mathrm{~A}$ corporate raider would acquire control and exploit outside investors. Hence, controlling shareholders cannot sell the company at firm value. On the contrary, in order to prevent a control grab, they need to hold on to their control, leaving the company with a

22 L. Timmerman, 'Bescherming van minderheidsaandeelhouders tegen een meerderheidsaandeelhouder in een rechtsvergelijkend perspectief' in Nederlands ondernemingsrecht in grensoverschrijdend perspectief (Kluwer 2003) 83.

23 L.A. Bebchuk, 'A Rent-Protection Theory of Corporate Ownership and Control' (1999) NBER Working Paper 7203, 24-25. This view is consistent with empirical findings that the level of investor protection correlates negatively with ownership concentration: R. La Porta, F. Lopez-de-Silanes and A. Schleifer, 'Corporate Ownership Around the World' (1999) 54 J.Fin. 471. This view is also consistent with empirical findings that the level of private benefits of control correlates positively with ownership concentration: A. Dyck and L. Zingales, 'Private Benefits of Control: An International Comparison' (2004) 59 J.Fin. 537.

24 A. Dyck and L. Zingales, 'Private Benefits of Control: An International Comparison' (2004) 59 J.Fin. 537, 541; M.J. Roe, Political Determinants of Corporate Governance (Oxford University Press, 2003) 169; H. Demsetz and K. Lehn, 'The Structure of Corporate Ownership' (1985) 93 J.Pol.Econ. 1155, 1158.

25 A. Schleifer and R.W. Vishny, 'Large Shareholders and Corporate Control' (1986) 94 J. Pol.Econ. 461; J.S.S. Edwards and A.J. Weichenrieder, 'Ownership Concentration and Share Valuation' (2004) 5 German Economic Review 143. Similarly with regard to closed corporations: M. Bennedsen and D. Wolfenzon, 'The balance of power in closely held corporations' (2000) 58 J.Fin.Econ. 113. See for an overview of empirical studies: B.Y. Lai, 'Are Independent Directors Effective Corporate Monitors? An Analysis of the Empirical Evidence in the USA and Canada', https://ssrn.com/abstract=2781671, 351.

26 L.A. Bebchuk and M.J. Roe, 'A Theory of Path Dependence in Corporate Ownership and Governance’ (1999) 52 Stan.L.Rev. 127, 147.

27 L.A. Bebchuk, 'A Rent-Protection Theory of Corporate Ownership and Control' (1999) NBER Working Paper 7203. 
suboptimal ownership structure. This also explains why contracts are not perfect substitutes for (good) company law..$^{28}$ Indeed, companies may voluntarily adopt minority protection in the articles and, by doing so, lower the cost of capital. However, controlling shareholders may unilaterally amend the articles. Legal constraints on their ability to do so are imperfect. ${ }^{29}$ Hence, the contracting mechanism does not help the controlling shareholders who wish to sell the control to the market.

A 'lock on control' affects firm performance in two ways. First, a shareholder cannot make the company infinitely issue new shares without diluting his own shares and thus losing control. Depending on the company's external financing requirement, reduced market capitalization may negatively impact firm value. ${ }^{30}$ This obstacle is tempered to the extent that a jurisdiction allows for deviations from the one share, one vote principle. ${ }^{31}$ Second, retaining control is

28 To be sure, contracts play a role to the extent that altering the bylaws require time and qualified majorities. Cf. M.J. Roe, 'The Institutions of Corporate Governance' in C. Ménard and M.M. Shirley (eds), Handbook of New Institutional Economics (Springer, Dordrecht 2005) 388.

29 Two types of restrictions exist. First, qualified majorities may be imposed. Such restrictions exist in Belgium (Article 558 C.Soc.), France (L.225-96 C.Com.) and the United Kingdom (S. 283 CA 2006), but not in the Netherlands (Article 2:121 NBW) and Delaware $(\$ 109$ DGCL). Second, it may be required that amendments do not harm minority shareholders. However, such restrictions are generally limited in scope. In Belgium and France, Article 560 C.Soc. c.q. L.225-99 C.Com. only apply to amendments if a company has issued different classes of shares and the resolution alters to the rights attached to the shares hold by the minority shareholders. In the Netherlands, Article 2:122 only applies to resolutions that increase or decrease capital. In the United Kingdom, courts have elaborated a rule that power to alter the articles "must be exercised, not only in the manner required by law, but also bona fide for the benefit of the company as a whole". However, according to scholars, courts are rather reluctant to cancel resolutions that harm minority shareholders: J. Dine and M. Koutsas, Company Law (Palgrave 2014) 35; Z. Cohen, 'Fiduciary Duties of Controlling Shareholders: A Comparative View' (1991) 12 U.Pa.J.Int'l Bus.L. 379. Furthermore, it should be taken into account that controlling shareholders may have the company entered into a merger agreement with a subsidiary. If the company disappears, its articles do not apply to subsequent related party transactions entered into by the subsidiary.

30 P. Bolton and E.L. Von Thadden, 'Blocks, Liquidity, and Corporate Control' (1998) 53 J.Fin. 1, 3. Similarly: H. Demsetz and K. Lehn, 'The Structure of Corporate Ownership' (1985) 93 J.Pol.Econ. 1155, 1158 ("Both these effects of size imply greater diffuseness of ownership the larger is the firm.")

31 Examined jurisdiction require strict proportionality of voting rights in listed companies: Article 592 C.Soc. (Belgium); L.225-122 C.Com. (France); Article 2:206a NBW (The Netherlands); S. 561 CA 2006 (United Kingdom). France, however, now allows socalled loyalty shares, which carry double voting rights if they are held by the same shareholder for at least two years (L.225-123 C.Com.). A similar system is currently 
especially inconvenient upon retirement of the founder. A founder could sell the controlling block on the private market, but interest in buying is low if the cost of control exceeds the benefits of it. The inability of selling the company to the market often means that it remains in the hands of relatives. However, heirs are not necessarily more capable than professional managers.

\section{Are General Principles of Company Law Helpful?}

\section{A. Board Autonomy}

5. Board autonomy is undermined in controlled companies - Companies are generally managed by or under the direction of the board of directors. ${ }^{32}$ In the course of the twentieth century, courts and legislators have attributed more authority to boards..$^{33}$ If ownership is dispersed, boards are better informed than shareholders and thus more capable of monitoring management. ${ }^{34}$ If ownership is concentrated, boards could also protect minority shareholders against blockholders. ${ }^{35}$ These objectives require some degree of 'board autonomy', which means that boards are shielded from direct interference by shareholders. In most jurisdictions, a majority of shareholders cannot give direct instructions to the board. ${ }^{36}$ Boards are thus legally empowered to favour the company's interest over the interest of a controlling shareholder. ${ }^{37}$

considered by the Belgian parliament: Article art. 7:53 Wetsontwerp tot invoering van het Wetboek van vennootschappen en verenigingen en houdende diverse bepalingen, Parl.St. Kamer 2017-2018, nr. 3119/002.

32 Article 522, $\mathbb{} 1$ C.Soc. (Belgium); L.225-17 C.Com. (France); Article 2:129 NBW (the Netherlands); $\mathbb{1} 141$ DGCL (Delaware). For the United Kingdom, the UK Corporate Governance Code provides: "Every company should be headed by an effective board which is collectively responsible for the long-term success of the company."

33 S. Cools, "The Dividing Line Between Shareholder Democracy and Board Autonomy: Inherent Conflicts of Interest as Normative Criterion' (2014) 2 ECFR 258, 263.

34 M.J. Roe, 'The Institutions of Corporate Governance' in C. Ménard and M.M. Shirley (eds), Handbook of New Institutional Economics (Springer, Dordrecht 2005) 379-380.

35 S. Cools, 'The Dividing Line Between Shareholder Democracy and Board Autonomy: Inherent Conflicts of Interest as Normative Criterion' (2014) 2 ECFR 258, 263.

36 Belgium: Kh. Brussels 15 February 1982, RPS 1982, 115 (Commercial Court of Brussels). France: Cass. 4 June 1946, JCP 1947, II, 3518. The Netherlands: HR 21 Januari 1955 , NJ no 43 . However, the articles may provide that board members need to comply with the general meeting's recommendations (Article 2:129, para $4 \mathrm{NBW}$ ).

37 Eg De Wulf considers the absence of injunction rights as an important device for the protection of minority shareholders: H. De Wulf, Taak en loyauteitsplicht van het bestuur in de nv (Intersentia 2002) 340. 
However, in a controlled company, directors are not in a position to exercise real independent judgment. ${ }^{38}$ Most of the examined jurisdictions have one-tier boards, which means that controlling shareholders influence both executive and non-executive directors. ${ }^{39}$ First, a controlling shareholder usually has a decisive influence over the appointment of directors. While the appointment of directors technically falls within the ambit of the general meeting, this is often decided by (simple) majority. ${ }^{40}$ Hence, one could say that controlling shareholders have the power to unilaterally appoint (most) directors. Similarly, controlling shareholders have the power to unilaterally remove directors from the board. This follows from the general rule that directors are - at least as a default rule - revocable at will. ${ }^{41}$ Even if boards are initially staggered, controlling shareholders have the power to amend the bylaws or articles in order to remove directors at will. Third, a controlling shareholder determines the directors' salary, either directly or indirectly through the board. Remuneration power gives controlling shareholders an additional tool to reward or punish directors for their loyalty or disloyalty. ${ }^{42}$ Controlling shareholders are legally empowered to pursue a carrot-and-stick approach and to induce boards to comply with their desires. ${ }^{43}$ Board autonomy in controlled companies is thus

38 S. Cools, 'Europe's Ius Commune on Director Revocability' (2011) ECFR 199, 205; D. A. DeMott, 'The Mechanics of Control' (1999) 13 Conn.J.Int.L. 233, 237.

39 In these jurisdictions, two-tier boards are generally available, though merely optional.

40 Article 518, $\mathbb{2}$ C.Soc. (Belgium); L.225-18 (France); Article 2:132 (one-tier board), Article 2:142 and 2:158 (two-tier board) NBW (the Netherlands); $\$ 211$ (b) DGCL (Delaware). In the United Kingdom, the law does not regulate the appointment of directors, which means that the (controlling) shareholder(s) have considerable latitude in the articles: P.L. Davies and S. Worthington, Gowers' Principles of Modern Corporate Law (Sweet \& Maxwell 2016) 367. In the supervisory board of large Dutch companies, one third of the members needs to be nominated by the employees council (Article 2:158, para $6 \mathrm{NBW})$.

41 Article 518, $\ 3$ C.Soc. (Belgium); L.225-18 C.Com. (France); Article 2:129 (one-tier) and Article 2:144 (optional two-tier) NBW (the Netherlands); Article 168 (1) Companies Act 2006 (hereafter CA 2006) (United Kingdom; $\$ 141$ (k) DGCL (Delaware). See for a discussion: S. Cools, 'Europe's Ius Commune on Director Revocability' (2011) ECFR 199.

42 K. Kastiel, 'Executive Compensation in Controlled Companies' (2015) 90 Ind.L.J. 1131, 1139, 1142-1145.

43 L.A. Bebchuk and A. Hamdani, 'Independent Directors and Controlling Shareholders' (2017) 165 U.Pa.L.Rev. 1271, 1286-1290; P.L. Davies and S. Worthington, Gowers' Principles of Modern Corporate Law (Sweet \& Maxwell 2016) 632; M. Gutiérrez and M. Sáez, 'Deconstructing Independent Directors' (2013) 13 JCLS 63, 73; R. Barker and I. Chiu, 'Protecting minority shareholders in blockholder-controlled companies: evaluating the UK's enhanced listing regime in comparison with investor protection regimes in New York and Hong Kong' (2014) 10 CMLJ 98, 100. 
substantially eroded. ${ }^{44}$ Accordingly, boards cannot be assumed to adequately scrutinize related party transactions desired by the controlling shareholder. To be sure, directors could be exposed to liability when they fail to favour the company's interest over that of controlling shareholders. However, the business judgment rule and procedural barriers to derivative suits erode the legal enforcement of fiduciary duties (infra, no 13).

One approach to agency problems is the establishment of two-tier boards, which are, among the examined jurisdictions, only mandatory in the Netherlands. ${ }^{45}$ In so-called 'large companies' ('structuurvennootschappen'), the supervisory board elects, and thus monitors, the executive board. ${ }^{46}$ The supervisory board is composed of directors who are not employed by the company, a group company or a labour union. ${ }^{47}$ Separating executive directors and nonexecutive directors is thought to lead to a better monitoring of management on the one hand and allows the participation of other stakeholders in boards on the other hand. ${ }^{48}$ Additional features of the supervisory board's composition suggest that the Dutch two-tier system also offers some protection to minority shareholders in controlled companies. First, members of the supervisory board should be nominated by either the (other members of) the supervisory board or the works council. ${ }^{49}$ Second, members of the supervisory board are elected for four years and are in principle not revocable at will. If shareholders wish to remove a director at will, they need to dismiss the entire supervisory board..$^{50}$ This limits the influence of large shareholders over the management's decisionmaking process. ${ }^{51}$ However, it is not impossible for controlling shareholders to hold on to their control and influence over the board..$^{52}$ If they limit the

44 cf. McQuade v. Stoneham, 263 NY 323 (1934): "that directors exercise in all matters an independent judgment in practice often yields to the fact that the choice of directors lies with the majority stockholders and thus gives the stockholders a very effective control of the action by the board of directors."

45 Article 2:158 NBW.

46 Article 2:162 NBW.

47 Article 2:159 NBW. Additional requirements are 'imposed' bij de III.2.2. of the Dutch Corporate Governance Code, available at www.commissiecorporategovernance.nl.

48 S. Cools, 'The Dividing Line Between Shareholder Democracy and Board Autonomy: Inherent Conflicts of Interest as Normative Criterion' (2014) 2 ECFR 258, 263; K. J. Hopt, 'The German Two-Tier Board: Experience, Theories, Reforms' in Comparative Corporate Governance - The State of the Art and Emerging Research (Clarendon Press 1998) 227.

49 Article 2:158 NBW.

50 Article 2:161a NBW.

51 M. Martynova and L. Renneboog, 'An International Corporate Governance Index' in The Oxford Handbook of Corporate Governance (Oxford University Press 2013) 111.

52 The mandatory regime is a compromise between two competing objectives: the protection of investors and the incorporation of companies which are part of international 
number of supervisory directors to three, which is the statutory minimum ${ }^{53}$, removing the entire board is not very burdensome. Second, the special regime for large companies is subject to a couple of important exceptions. It does not apply to controlled companies whose majority shareholder is subject to the regime. ${ }^{54}$ Moreover, the provision that the supervisory board elects the executive board members does not apply to companies which are controlled by a large shareholder the majority of whose employees work outside the Netherlands..$^{55}$ These exceptions leave room for regulatory arbitrage by badly intentioned controlling shareholders. While the Dutch two-tier board protects minority investors against controlling shareholders to some extent, it does not prevent related party transactions.

6. Independent directors do not (entirely) constrain controlling shareholders - Another approach to agency problems is the appointment of independent directors to the board. This approach serves a similar purpose as twotier boards: separating executive and non-executive directors. ${ }^{56}$ However, the impact of this approach in controlled companies is even more modest than the establishment of two-tier boards. Independent directors originate in the widely held company. ${ }^{57}$ Shareholders in such companies often do not exercise their voting rights, because the cost of doing so exceeds the benefits, considering their very small equity stake. ${ }^{58}$ Hence, directors are unchecked and if market forces do not constrain them, they trade off corporate value to increase their own utility. ${ }^{59}$ Executive directors have slack and do not manage their companies well. They spoil non-executive directors in return for lenient monitoring. ${ }^{60}$ Since independent directors are financially independent from the company and lack financial or personal ties with the CEO and other officers,

concerns: P. Van Schilfgaarde, J. Winter and J.B. Wezeman, Van de BV en de NV (Kluwer 2013) 446.

53 Article 2:158, para $2 \mathrm{NBW}$.

54 Article 2:153, para 3 NBW.

55 Article 2:155 NBW.

56 cf. M. Martynova and L. Renneboog, 'An International Corporate Governance Index' in The Oxford Handbook of Corporate Governance (Oxford University Press 2013) 108-109.

57 A good overview is given in H. Baum, 'The Rise of the Independent Director: A Historical and Comparative Perspetive', Max Planck Institute for Comparative and International Private Law, Research Paper Series 16/20.

58 S.J. Grossman and O.D. Hart, 'Takeover bids, the free-rider problem, and the theory of the corporation' (1980) 11 Bell J.Econ. 42, 42; W.O. Douglas, 'Directors who do not direct' (1934) 47 Harv.L.Rev. 1305.

59 W.I. Baumol, Business behavior, value and growth (Harcourt, Brace and World 1967).

60 X, 'Developments in the Law: Corporations and Society' (2004) 117 Harv.L.Rev. 2169, 2186. 
they are thought to improve corporate governance through a better monitoring of management. ${ }^{61}$

First of all, independent directors do not curb self-dealing if they do not hold a veto right over related party transactions. On a more fundamental level, the impact of independent directors on corporate governance in controlled companies is questionable. ${ }^{62}$ Within the framework of such companies, director independence means that the director has no ties with the controlling shareholder. ${ }^{63}$ However, under current legislation, an independent director cannot be elected without the approval of the controlling shareholder ${ }^{64}$ Similarly, a controlling shareholder retains the power to remove the independent directors. Put differently, although a controlling shareholder cannot appoint (former) affiliates, he is still free to redeem loyalty by using his power to appoint and remove independent directors. ${ }^{65}$ Of course, independent directors may be less financially dependent on their position than other directors and managers. However, the controlling shareholder holds a power over the independent directors that managers in the widely held company do not have. Hence, under the NYSE Listing Rules, controlled companies are exempt from director

61 See on this question: B.Y. Lai, 'Are Independent Directors Effective Corporate Monitors? An Analysis of the Empirical Evidence in the USA and Canada', https://ssrn.com/ abstract=2781671 (accessed January 2017).

62 G. Ferrarini and M. Filippelli, 'Independent directors and controlling shareholders around the world' (2014) ECGI Law Working Paper 258/2014, 30-33; L. Enriques, H. Hansmann, R. Kraakman and M. Pargendler, 'The Basic Governance Structure: Minority Shareholders and Non-Shareholder Constituencies' in R. Kraakman et al. (eds), The Anatomy of Corporate Law (Oxford University Press 2017) 86; B.Y. Lai, 'Are Independent Directors Effective Corporate Monitors? An Analysis of the Empirical Evidence in the USA and Canada', https://ssrn.com/abstract=2781671 (accessed January 2017) 329 and 354.

63 According to a EU Recommendation, a "director should be considered to be independent only if he is free of any business, family or other relationship, with the company, its controlling shareholder or the management of either, that creates a conflict of interest such as to impair his judgement.", Article 16 Commission Recommendation 2005/162/ EC of 15 February 2005 on the role of non-executive or supervisory directors of listed companies and on the committees of the (supervisory) board (2005) L52/51.

64 Under the U.K. Listing Rules, controlled companies are required to appoint one independent director approved by the minority shareholders (infra, no 24)

65 L.A. Bebchuk and A. Hamdani, 'Independent Directors and Controlling Shareholders' (2017) 165 U.Pa.L.Rev. 1271, 1286-1290; M. Gutiérrez and M. Sáez, 'Deconstructing Independent Directors' (2013) 13 JCLS 63, 75. Similarly, Lai claims that independent directors face duty of loyalty claims for colluding with controlling shareholders: B. Y. Lai, 'Are Independent Directors Effective Corporate Monitors? An Analysis of the Empirical Evidence in the USA and Canada', https://ssrn.com/abstract=2781671 (accessed January 2017) 93. 
independence requirements. ${ }^{66}$ The underlying idea of this exemption is that independent directors redress the excesses of board autonomy in widely held companies, but not the lack of board autonomy in controlled companies.

\section{B. Equal Treatment of Shareholders}

\section{Related party transaction fall outside ambit of equal treatment rules -} Shareholder equality is often considered a fundamental norm of company law in European jurisdictions. ${ }^{67}$ Unless otherwise provided by the articles, all shares of a particular class represent the same claim on corporate assets. ${ }^{68}$ Hence, as a default rule, each share entitles its owner to an equal amount upon payment of dividends or liquidation. ${ }^{69}$ More importantly, equal treatment of shareholders is required by EU law upon issuance of new shares or repurchase of existing shares. ${ }^{70} \mathrm{~A}$ controlling shareholder could employ these transactions

66 Section 303A.00 NYSE Listed Company Manuel, available at http://nysemanual.nyse. $\mathrm{com} / \mathrm{lcm}$.

67 OECD, 'Related Party Transactions and Minority Shareholder Rights' (2012) 52; D. A. Verse, Der Gleichbehandlungsgrundsatz im Recht der Kapitalgesellschaften (Mohr Siebeck 2006) 1. Belgium: Article 551bis C.Soc.; S. Cools, 'De liquidatiereserve: aard, besluitvorming, vennootschapsbelang en aandeelhoudersgelijkheid' (2015) TRV 703, 710; J.M. Nelissen Grade, 'Het gelijkheidsbeginsel in het bijzonder bij inkoop van eigen aandelen en kapitaalvermindering' in Knelpunten van dertig jaar vennootschapsrecht (Biblo 1999) 632-633. France: D. Carreau and H. Letréguilly, 'Offres publiques (OPA, OPE, OPR)' in Répertoire de droit des sociétés (Dalloz 2012) no 133. The Netherlands: Article 2:92, para 2 NBW; H.M. Vletter-van Dort, Gelijke behandeling van beleggers bij informatieverstrekking (Kluwer 2001) 11-13; M. Brink, 'Gelijkheid van aandeelhouders?' (1997) TVVS 174-178. By contrast, the Supreme Court of Delaware rejected shareholder equality as a normative principle: Nixon v Blackwell 626 A.2d 1366 (1993), with reference to F.H. Easterbrook and D.R. Fischel, The Economic Structure of Corporate Law (Harvard University Press 1991) 110. The reasoning is that boards and controlling shareholders should treat fairly; fair treatment, however, does not necessarily imply equal treatment. See for a discussion: J.D. Cox, 'Equal Treatment for Shareholders: An Essay’ (1997) 19 Cardozo L.Rev. 615.

68 V. Brudney, 'Equal Treatment of Shareholders in Corporate Distributions and Reorganizations’ (1983) 71 Cal.L.Rev. 1072, 1074.

69 Article 30 C.Soc. (Belgium); Article 1844-1 C.Civ. (France); Article 2:92, para 1 NBW (The Netherlands); Birch v Cropper (1889) UKHL 14 AC 525 (United Kingdom) ("Every person who becomes a member of a company limited by shares of equal amount becomes entitled to a proportionate part in the capital of the company, and, unless it be otherwise provided by the regulations of the company, entitled, as a necessary consequence, to the same proportionate part in all the property of the company, including its uncalled capital.").

70 Article 46 Directive 2012/30/EU of the European parliamant and the Council of 25 October 2012, OJ L315/74 (hereafter: Capital Directive). 
to discriminate outside investors and, by doing so, expropriate them. Upon share repurchase, he would determine the price above market price or fair value and then sell his own shares. Upon issuance of new shares, he would determine the price below market price or fair value and then buy the shares himself. Pursuant to Article 33 Capital Directive, incumbent shareholders have pre-emption rights, which give them the right to buy newly issued shares in proportion to their current amount of shares. ${ }^{71}$ Hence, a controlling shareholder cannot divert firm value without giving the same opportunity to minority shareholders. Similar restrictions on controlling shareholders exist for share repurchases. ${ }^{72}$

Equal treatment rules, however, do not prevent a controlling shareholder from engaging in self-dealing. The common denominator between these applications of the equal treatment rule is the interaction between the company and its (future) members in their capacity as shareholders. The rule cannot be analogously applied to market transactions between the company and a third party, even if the latter is a shareholder. After all, self-dealing transactions generally comply with the equal treatment rule, because from a legal point of view they impact all shareholders to the same extent. Consider a parent-subsidiary merger. From a formal point of view, the exchange ratio applies to the controlling shares and minority shares alike. However, only minority investors are adversely affected by it, because the parent does not issue shares to himself. Hence, even if jurisdictions require that a merger agreement treats all shareholders (of the same class) equally, such a rule does not prevent controlling shareholders from shuffling away value through intra-group mergers.

\section{Transparency}

\section{Transparency does not constrain controllers because markets are imper-} fect - Listed companies must comply with a considerable number of financial reporting requirements. One of those requirements is the disclosure of related party transactions $s^{73}$, in both periodic reports and ad hoc notifications ${ }^{74}$. Transparency rules reinforce the market mechanism. By lowering search costs ${ }^{75}$, they make it easier for investors to distinguish between honest and dishonest

71 Article 592 C.Soc. (Belgium); L.225-132 C.Com. (France); Article 2:206a NBW (The Netherlands); S. 561 CA 2006 (United Kingdom).

72 Articles 21 and 46 Capital Directive.

73 Eg European Union: IAS 24.18/19.

74 Eg United Kingdom: LR 11.1.7; United States: 17 CFR 229.440.

75 Z. Goshen and G.P. Ovsky, 'The Essential Role of Securities Litigation' (2006) 55 Duke L.J. 711. 
controlling shareholders. To be sure, disclosure rules do not offer protection against concluded transactions ex post. They merely deter controlling shareholders ex ante: disclosure of value-decreasing related party transactions would lead to lower share prices and thus a higher cost of capital. ${ }^{76}$ However, not all controlling shareholders are constrained by reputation and the price of capital. ${ }^{77}$ If the competition on product markets is weak, companies may not need to raise much capital in order to remain competitive. The deterrence value of transparency rules is then low. Moreover, transparency does not prevent controlling shareholders from robbing the company through one-shot transactions. The risk that controlling shareholders 'take the money and run', persists. ${ }^{78}$

On the other hand, the information provided does not always affect the behaviour of investors. ${ }^{79}$ First, disclosed related party transactions may be either fair (value-increasing) or unfair (value-decreasing). Investors generally need to evaluate the fairness of transactions themselves. Many reasons could prevent investors from making that evaluation. The reciprocity of a transaction is difficult to assess if there is no thick market, for instance if goods and services are very specific. Making the evaluation requires time and effort that outside investors are not willing to spend for every company in which they invest. To be sure, institutional investors often provide useful signals to the market. However, shareholder activism is often proportionate to the strength of the financial markets. If financial markets are weak, which may be the case if legal protection of minority shareholders is low, one cannot rely on the market mechanism to curb self-dealing. Second, necessary information is often unavailable to outside investors. Van der Elst demonstrates that accounting information does not necessarily allow shareholders to assess the importance of related party transactions to the company. ${ }^{80}$ Min claims that companies have too much latitude in determining whether a transaction is 'material', affecting

76 L. Enriques, G. Hertig and H. Kanda and M. Pargendler, 'Related-Party Transactions' in R. Kraakman et al. (eds), The Anatomy of Corporate Law (Oxford University Press 2017) 147.

77 M.J. Roe, 'The Institutions of Corporate Governance' in C. Ménard and M.M. Shirley (eds), Handbook of New Institutional Economics (Springer, Dordrecht 2005) 378-379.

78 S. Djankov, R. La Porta, F. Lopez-de-Silanes and A. Schleifer, 'The law and economics of self-dealing' (2008) 88 J.Fin.Econ. 430, 431.

79 M. Pizzo, 'Round Touble on Corporate Governance in Europe' (2009), https://ssrn. com/abstract=1441173 (accessed Januari 2017) 17.

80 C. Van der Elst, 'Empowering the Audit Committee and the Auditor in Related Party Transactions’ (2016) ECGI Law Working Paper 318/2016, 14. 
the reliability of all information provided the market. ${ }^{81}$ In sum, financial reporting does not adequately constrain controlling shareholders. ${ }^{82}$

\section{Inadequacy of Self-Dealing Mechanisms in Some Civil Law Jurisdictions}

9. Policymakers should not simply prohibit all related party transactions. ${ }^{83}$ After all, these transactions may well be value-increasing ${ }^{84}$, for instance because they are essential during the start-up phase of a company. ${ }^{85}$ The law should thus only prevent value-decreasing related party transactions. The most common mechanisms are prohibitions on voting, judicial review and special approval procedures. In this section, it is discussed that the law of Belgium, France and the Netherlands generally does not prevent conflicted shareholders from voting, but instead rely on either judicial review or special approval procedures. It is argued why these mechanisms, as implemented in said jurisdictions, do not provide adequate protection to minority shareholders against self-dealing by controlling shareholders. To this end, a comparison is drawn between said jurisdiction on the one hand, and the United Kingdom and Delaware on the other hand.

\section{A. Voting on Conflicted Transactions}

10. Voting prohibition considered incompatible with purpose of voting rights - U.K. Listing rules, applicable to all companies listed on an exchange in the United Kingdom, require that transactions between related parties must be ratified by shareholders and that the related party must refrain from

81 G. Min, 'The SEC and the Courts' Cooperative Policing of Related Party Transactions' (2014) Colum.Bus.L.Rev. 663.

82 L. Enriques, 'Related Party Transactions: Policy Options and Real-World Challenges (with a Critique of the European Commission Proposal) (2015) 16 EBOR 1, 21; European Commission, 'Action Plan: European Company law and corporate governance - a modern legal framework for more engaged shareholders and sustainable companies', COM (2012) 740, final, 9.

83 S. Djankov, R. La Porta, F. Lopez-de-Silanes and A. Schleifer, 'The law and economics of self-dealing' (2008) 88 J.Fin.Econ. 430, 431.

84 L. Enriques, G. Hertig and H. Kanda and M. Pargendler, 'Related-Party Transactions' in R. Kraakman et al. (eds), The Anatomy of Corporate Law (Oxford University Press 2017) 146-147.

85 C. Van der Elst, 'Empowering the Audit Committee and the Auditor in Related Party Transactions' (2016) ECGI Law Working Paper 318/2016, 2; M. Pizzo, 'Round Touble on Corporate Governance in Europe’ (2009), https://ssrn.com/abstract=1441173 (accessed Januari 2017) 11. 
voting. ${ }^{86}$ Related party transactions must thus be approved by a majority of minority shareholders. This rule applies both to shareholder decisions (resolutions) and decisions which normally fall within the ambit of the board. In Belgium, France and the Netherlands, controlling shareholders do not need to refrain from voting on transactions in which they have a personal interest. ${ }^{87}$ Quite the contrary, it is argued that the purpose of voting rights is to allow shareholders to serve their own interest within the company. ${ }^{88}$ Prohibitions on voting are thus considered incompatible with the nature and purpose of voting rights. ${ }^{89}$ In addition, the listing rules of Euronext do not impose a specific rule on related party transactions. There is one exception to this rule: under French law, board decisions which entail a 'regulated contract' (convention contrôlée) should be approved by the general meeting, at which a controlling shareholder is not entitled to vote (infra, no 15). This exception should be strictly applied: according to the French Supreme Court, articles that extend the prohibition to other transactions, violate the mandatory rules on voting rights..$^{90}$

\section{B. Deferential Standards of Review}

11. Standing to sue alone is not sufficient for adequate minority protection - The level of minority protection against self-dealing is often measured by the minority shareholders' ability to challenge a corporate decision in court. This means that minority shareholders are thought to be protected if courts

86 L.R. 11.1.7.

87 Belgium: J.M. Nelissen Grade, 'De la validité et de l'exécutions de la convention de vote dans les sociétés anonymes' (1991) RCJB 214, 239; P. Ernst, Belangenconflicten in naamloze vennootschappen (Intersentia 1997) 619; Y. De Cordt, L'égalité entre actionnaires (Bruylant 2004), 759. The Netherlands: W.J. Slagter en B.F. Assink, Compendium Ondernemingsrecht, vol 1 (Kluwer 2013) 859; P. Van Schilfgaarde, Van de BV en de NV (Kluwer 2013) 229;. In France, this principle has been recognized by the Supreme Court, although the judgments do not relate to controlling shareholders: Cass. 29 July 1925, DP 1926, I, 17; Cass. 4 May 2010, LPA 2010, no 144.

88 HR 13 november 1959, NJ 1960, 1073, no 472 ("dat toch den aandeelhouder eener N.V. in het hem verleende stemrecht niet een recht in het belang van anderen is toevertrouwd, doch een eigen recht is gegeven om zijn belang in de vennootschap te dienen."). Similarly: D. van Gerven, 'Moet de aandeelhouder wel stemmen in het vennootschapsbelang?' (2013) TRV 671; J.M.M. Maeijer, 'Het belangenconflict in de naamloze vennootschap' in Verspreide geschriften van J.M.M. Maeijer (Kluwer 2009) 141, 158; F. T'Kint, 'Les actions et le droit de vote' (1989) RPS 242, 243.

89 S. Cools, De verdeling van beslissingsbevoegdheden tussen algemene vergadering en raad van bestuur in de NV (Roularta 2015) 174.

90 Cass. 9 February 1999, Bull. Joly 567 ("une suppression du droit de vote non prévue par la loi."). 
have the power to either rescind a transaction, or find directors and/or shareholders liable for unsound transactions. In Belgium and France, shareholders may indeed file a liability suit against directors on behalf of the company. ${ }^{91}$ Such derivative suits are unavailable in the Netherlands. ${ }^{92}$ However, all three jurisdictions allow all shareholders individually to file a rescission suit. ${ }^{93}$

While minority shareholders' standing to sue is indeed important for the overall level of legal protection, it is far from sufficient in that regard. First, it should be taken into account that minority shareholders face procedural barriers, relating to their lack of information, but especially due to litigation cost. ${ }^{94}$ In civil law jurisdictions, plaintiffs bear litigation cost for derivative suits if they lose, while profits belong to the company if they win. This discourages shareholders from initiating suit and leads to the underdeterrence of directors (and controlling shareholders). In the United States, this inconvenience is solved through contingency fees, which are unavailable in civil law jurisdictions. ${ }^{95}$ As a result, derivative suits in civil law jurisdictions may not have the same impact as their U.S. counterparts. Second, it is important to know which standard of review courts apply. If courts defer to the discretion of corporate insiders, liability and rescission suits may not provide the protection that minority shareholders need. In this section, it is discussed that lenient standards of review affect the ability of judicial review to curb self-dealing.

Under Delaware company law, transactions between a company and its controlling shareholders are reviewed under the standard of 'entire fairness', which means that the transactions must meet the conditions of 'fair dealing' and 'fair price'. ${ }^{96}$ The entire fairness review is based on the idea that controlling shareholders owe fiduciary duties to the company and the minority shareholders. ${ }^{97}$ Fiduciaries owe a duty of loyalty, which means inter alia that they

91 Article 562 C.Soc. (Belgium); Article 1843-5 C.Civ. (France). In Belgium, plantiffs should collectively hold at least 1 per cent of the voting rights.

92 M.J. Kroeze, Afgeleide schade en afgeleide actie (Kluwer 2004), 153.

93 Article 178 C.Soc. (Belgium); Article 2:15, para 3, a NBW (the Netherlands). For France, see Cass. 16 October 1972, no 70.13691, available at www.legifrance.gouv.fr ('action sociale ut singuli' cannot only be used for liability claims, but also to seek rescission).

94 K.J. Hopt, 'Conflict of Interest, Secrecy and Insider Information of Directors, A Comparative Analysis' (2013) ECFR 167, 190.

95 C. De Backere and N. De Lathauwer, 'Contingent Fees: Beyond the intuitive threat' (2013) 49 Jura Falc. 101.

96 Weinbergerv. UPO, Inc. 457 A.2d 701 (Del. 1983).

97 Sinclair Oil v. Levien, 280 A.2d 717 (Del. 1971); Getty Oil Company v. Skelly Oil Co., 267 A2d 883 (Del. 1970). See for convincing arguments that such fiduciary duties should apply to all shareholders: I. Anabtawi and L.A. Stout, 'Fiduciary Duties for Activist Shareholders' (2008) 60 Stan.L.Rev. 1255. 
may not derive any personal benefit from their offices and, to that end, must avoid conflicts of interests. ${ }^{98}$ On the occurrence of such conflict, courts are entitled to examine whether fiduciaries - directors or controlling shareholders - have used their power to the benefit of the company. This means that the transaction must be 'fair' to the company. ${ }^{99}$ If demand is excused ${ }^{100}$, directors and controlling shareholders bear the burden of proof that the transaction is fair. ${ }^{101}$ Delaware courts accept that the burden of proof shifts to the minority shareholders if the transaction is approved either by an independent committee or by a majority of minority shareholders. ${ }^{102}$

\section{Shareholder decisions: shareholders do not have fiduciary duties in civil} law jurisdictions - In Belgium, France and the Netherlands, related party transactions approved by the general meeting are not subject to any specific standard of review. This means that resolutions involving a related party transaction must meet the same criteria as other, non-conflicted corporate decisions. It is generally held that in the exercise of voting rights, a shareholder is not legally bound to subordinate his own personal interest over the interest of the company. ${ }^{103}$ This rule is derived from the idea that shareholders are

98 R. Munday, Agency. Law and Principles (3rd ed, Oxford University Press 2016) no 8.20 and 8.33 .

99 cf. $\$ 144$ (a) para 3 DGCL.

100 Shareholders may not bring suit unless they first make demand on the of directors or demand is excused (Federal Rule 23.1). Demand is excused when it is futile. The Delaware standard for futility is set in Aronson v. Lewis, 473 A.2d 814 (Del.1991): "the Court of Chancery in the proper exercise of its discretion must decide whether, under the particularized facts alleged, a reasonable doubt is created that: (1) the directors are disinterested and independent and (2) the challenged transaction was otherwise the product of a valid exercise of business judgment."

101 American Law Institute (ed), Principles of Corporate Governance: Analysis and Recommendations (ALI Publishers 1994) 325-325, $\ 5.10$.

102 Committee of independent directors: Weinberger v. UPO, Inc. 457 A.2d 701 (Del. 1983) ('footnote 7’). Majority-of-minority vote: Rosenblatt v. Getty Oil Co., 493 A.2d 929 (Del. 1985); Kahn v. Lynch Communication Systems, 638 A.2d 1110 (Del.Ch. 1983). In a recent case, the Chancery Court accepted that if both mechanisms are cumulatively applied, the transaction is reviewed under the more lenient standard of business judgment: In re MFW Shareholders Litigations (67 A.3d 496 (Del. Ch. 2013); G. Subramanian, 'Fixing Freezeouts' (2005) 115 Yale L.J. 2.

103 Belgium: K. Geens and M. Wyckaert, Beginselen van Belgisch Privaatrecht. Verenigingen en Vennootschappen (Kluwer 2011) 263; Y. De Cordt, L'égalité entre actionnaires (Bruylant 2004) 654; P. Coppens, L'abus de majorité dans les sociétés anonymes (Imprimerie J. Duculot 1947) 75-83. France: P. Ledoux, Le droit de vote des actionnaires (LGDJ 2002) 129-159; J.M. Hauptmann, Le droit de vote de l'actionnaire en droit français et en droit allemand (Ph.D. thesis, Université de Nancy 1986) 568; F. Letellier, Le droit de vote de l'actionnaire (Domat-Montchrestien 1942) 85. The Netherlands: B. Kemp, Aandeelhoudersverantwoordelijkheid: De positie en rol van de aandeelhou- 
owners of the company and thus cannot be considered 'fiduciaries' of the company or each other. ${ }^{104}$ Although scholars in several jurisdictions correctly question this reasoning and claim that controlling shareholders owe fiduciary duties to the company, similar to the duties of directors ${ }^{105}$, this is not the prevailing opinion in any of the civil law jurisdictions.

The free exercise of voting rights, however, is subject to one important qualification. Shareholders owe a general duty of good faith (Belgium and France) or reasonableness (The Netherlands). Within the framework of company law, this duty creates in each jurisdiction a prohibition on abuse of majority or minority, or simply a prohibition on abuse of power. Consistent with the general approach to good faith and reasonableness, however, this doctrine does not require fairness from the (controlling) shareholder(s). As an exception to the free exercise of rights, it only aims at preventing gross deviations from fairness. ${ }^{106}$ This means that a (controlling) shareholder only violates his duty to act in good faith, if he exercises his voting rights in a manner that manifestly exceeds the limits of a normal exercise of voting rights by a careful shareholder. ${ }^{107}$ Dutch law leads to a similar outcome through the use of the 'marginale toetsing', which means that courts need to defer to the discretion of the

der en aandeelhoudersvergadering (Kluwer 2015) 168; M. Koelemeijer, Redelijkheid en billijkheid in kapitaalvennootschappen (Kluwer 1999) 104.

104 Belgium: V. Simonart, 'Les conflits d'intérêts au sein de l'assemblée générale de la société anonyme en droit comparé' in Les conflits d'intérêts - Les conférences du centre de droit privé (Bruylant 1994) 235; V. Magnier, 'Les conflicts d'intérêts dans les principles of corporate governance' in Les conflicts d'intérêts dans le monde des affaires, in Janus à combattre (PUF 2006) 145. France: A.L. Champetierde Ribes-Justeau, Les abus de majorité, de minorité et d'égalité (Dalloz 2010) 55. The Netherlands: L. Timmerman, De dubbelrol in het (vennootschaps)recht' in De dubbelrol in het vennootschapsrecht (Kluwer 1999) 6. B. Kemp, Aandeelhoudersverantwoordelijkbeid: De positie en rol van de aandeelhouder en aandeelhoudersvergadering (Kluwer 2015) 193.

105 P.A. Foriers, 'Les devoirs fiduciaires de l'actionnaire de contrôle' in Quid leges sine cogatione? Enkele reflecties over vennootschapsrecht aangeboden aan Jean-Marie $\mathrm{Ne}$ lissen Grade (Biblo 2011) 40; L. Timmerman, 'Bescherming van minderheidsaandeelhouders tegen een meerderheidsaandeelhouder in een rechtsvergelijkend perspectief' in Nederlands ondernemingsrecht in grensoverschrijdend perspectief (Kluwer 2003) 88; D. Schmidt, Les droits de la minorité dans la société anonyme (Sirey 1970) 55; R. David, 'Le caractère social du droit de vote' (1929) J.Soc. 5.

106 P.A. Foriers, 'Les devoirs fiduciaires de l'actionnaire de contrôle' in Quid leges sine cogatione? Enkele reflecties over vennootschapsrecht aangeboden aan Jean-Marie $\mathrm{Ne}$ lissen Grade (Biblo 2011) 62.

107 J.M. Nelissen Grade, 'note sous Com. Bruxelles 31 mai 1991' (1991) TBH 935, 937, with reference to Cass. 10 September 1971, Arr.Cass. 1972, 31. 
boards and shareholders' meeting. ${ }^{108}$ In both jurisdictions, one of the most important criteria to evaluate a majority shareholder's behaviour is the proportionality test. ${ }^{109} \mathrm{~A}$ majority shareholder thus abuses his voting rights if his personal gains are disproportionally small in comparison with the harm to the company and the minority shareholders. By requiring disproportionality, and not inequality, courts allow controlling shareholders to make a profit at the expense of minority shareholders. ${ }^{110} \mathrm{~A}$ judgment from the Antwerp Court of Appeals illustrates this. ${ }^{111}$

\begin{abstract}
A holds $55 \%$ of share capital in listed company B and all shares in closed company C. A receives the offer from a third party to buy shares in company $\mathrm{D}$ at a favourable price. A decides to exercise the corporate opportunity through its subsidiary C. Subsequently, A merges B and C. The shares in $\mathrm{D}$ are valued 310EUR per share higher compared to the original acquisition price. Minority shareholders of $\mathrm{B}$ are thus diluted and A makes a large profit. They sue the company and seek nullification of the merger. They claim that the transaction is unfair. The Court of Appeals rejects their claim. The Court considers that "a controlling shareholder cannot be blamed for choosing the transaction that yield the highest profit to himself. The advantage for the controlling shareholder is considerable and makes up the disadvantage that minority shareholders experience."
\end{abstract}

The French Supreme Court seemingly imposes a more stringent standard of review within the framework of abuse of power. It held that a resolution constitutes an abuse of (majority) power if it is "incompatible with the company's interest and adopted with the sole purpose of favouring the majority shareholder(s) to the detriment of the minority shareholder(s)". ${ }^{112}$ This standard of review seems to apply to situations where a controlling shareholder diverts firm value through related party transactions. However, courts are rather reluctant to accept that a resolution is incompatible with the company's interests, even though the majority shareholder benefits from the underlying trans-

108 HR 12 juli 2013 ("dat de rechter terughoudendheid past bij de beoordeling of een orgaan van een rechtspersoon bij het nemen van een besluit alle in aanmerking komende belangen naar redelijkheid en billijkbeid beeft afgewogen en daarbij de nodige zorguuldigheid in acht heeft genomen."); C. Assers and M.J. Kroeze, Rechtspersonenrecht, I, De rechtspersoon (Kluwer 2015); 296 J.M.M. Maeijer, 'Het belangenconflict in de naamloze vennootschap' in Verspreide geschriften van J.M.M. Maeijer (Kluwer 2009) 158. The notion is also used in Belgium: K. Geens, 'De jurisprudentiële bescherming van de minderheidsaandeelhouder tegen door de meerderheid opgezette beschermingsconstructies' (1989) TPR 33, 45.

109 Belgium: Y. De Cordt, L'égalité entre actionnaires (Bruylant 2004) 761. The Netherlands: B. Kemp, Aandeelhoudersverantwoordelijkheid: De positie en rol van de aandeelhouder en aandeelhoudersvergadering (Kluwer 2015); Y. De Cordt, L'égalité entre actionnaires (Bruylant 2004) 761.

110 E. Wymeersch, 'Comment le droit pourrait aborder certain groupes de sociétés' in Mélanges offerts à Pierre Van Ommeslaghe (Bruylant 2000) 718.

111 Antwerp 22 May 2003, TRV 2005, 489 (Court of Appeals).

112 Cass. 18 April 1961, D 1961, 661 and S 1961, 257. 
action. ${ }^{133}$ A judgment illustrates how the French Supreme Court does not require lower courts to really scrutinize transactions between the company and its controlling shareholder. ${ }^{114}$

$\mathrm{A}$ and $\mathrm{B}$ are controlling shareholders of company $\mathrm{X}$ and sole shareholders of company $\mathrm{Y}$. In a general meeting of $\mathrm{X}$, it is decided that all activities of $\mathrm{X}$ will be transferred to a new building, which will be rented from company $\mathrm{Y}$. The monthly rent charged to $\mathrm{X}$ equals the monthly payment that $\mathrm{Y}$ owes under a lease-purchase agreement for that that building. The minority shareholder alleges that $\mathrm{A}$ and $\mathrm{B}$ make $\mathrm{X}$ pay for the acquisition of said building by $\mathrm{Y}$. They claim that this constitutes an abuse of majority power and seek rescission of the resolution to transfer the activities into a new building. The Supreme Court holds that said decision is not inconsistent with the company's interest, because during the years following the transaction, "the company's turnover has increased, which demonstrates that the transfer of activities and the payment of rent did not harm the company and that the [the minority shareholder] benefits from the expansion" 115 . It goes without saying that the overall increase of a company's turnover does not mean that every specific transaction is in the company's interest.

13. Board decisions: business judgment rule and 'group defences' shield directors from liability for self-dealing by controlling shareholders - Most related party transactions require approval by the board of directors, either because the decision falls within the ambit of the board (eg sale of an asset), or because the board prepares and negotiates shareholder decisions and has agenda power (eg merger). Unlike (controlling) shareholders, directors always owe fiduciary duties towards the company and thus all shareholders, including minority shareholders. ${ }^{116}$ This means that if directors approve a transaction that favours one shareholder exclusively, this would in principle constitute a violation of their fiduciary duties. However, directors are generally protected by the business judgment rule. This means that directors may favour one shareholder over another within their margin of appreciation. It could be suggested that directors should comply with a higher liability standard when approving a related party transaction, which is the case under Delaware law (supra, no 11). France has seemingly done so by making directors' collusion to

113 J.P. Sortais, 'Abus de droit (Majorité, minorité, égalité)' in Répertoire des sociétés (Dalloz 2003) no 16.

114 Cass. 4 October 1994, no 93.10934, available at www.legifrance.gouv.fr.

115 “Mais attendu que l'arrêt retient qu'il ressortait de la comparaison des bilans des années 1988, 1989 et 1990, que l'activité de la SARL X... avait augmenté, ce qui démontrait que le transfert des locaux et le paiement d'un loyer ne lui nuisaient pas et que la Saico profitait de cette expansion, ce dont il résultait que les mesures critiquées n'avaient pas été prises contrairement à l'intérêt général de la société X."

116 Belgium: H. De Wulf, Taak en loyauteitsplicht van bet bestuur in de nv (Intersentia 2002) 363; B. Tilleman, Bestuur van vennootschappen (die Keure 2005) 24. The Netherlands: L. Timmerman, De dubbelrol in het (vennootschaps)recht' in De dubbelrol in bet vennootschapsrecht (Kluwer 1999) 6. 
tunnelling a criminal act ('abus de biens sociaux'). Directors who use the assets of the company or their power over the company in a way that harms the company's interests are punished with imprisonment if they act in bad faith and thereby favour another company in which they are directly or indirectly interested. ${ }^{117}$ Similarly, in 2002, the Belgian legislature introduced a specific civil liability ground for directors who approved decisions or transactions that caused a loss to the company for the benefit of another company. ${ }^{118}$ However, both liability grounds are eroded by the so-called 'group defence'. This doctrine was developed by the French Supreme Court and was soon approved by scholars and courts in Belgium too. ${ }^{119}$

In Rozenblum, a company provided financial assistance to another company that was controlled by the same director, allegedly without sufficient consideration. The court held that financial assistance from one company to another is allowed under three cumulative conditions. ${ }^{120}$ First, the concerned companies must form a 'legal group', which means that they are connected through voting rights and shareholder control. Second, the transaction must be dictated by a common economic, social or financial interest, following from the fact that both companies are under a centralized management and strategy. Third, the transaction must not be without immediate consideration, not break the overall balance of reciprocity, and not exceed the company's financial possibilities.

While most scholars approve of the Rozenblum doctrine, a minority criticises it. ${ }^{121}$ The doctrine is based on the idea that companies derive benefits from being part of a corporate group. It is then accepted that those benefits offset and thus justify occasional expropriation by the controlling shareholders. Theoretically, it could be argued that the Rozenblum doctrine requires a balance between benefits and sacrifices in the long run, and that controlling

117 L.242-6, $3^{\circ}$ and $4^{\circ}$ C.Com.

118 Article 529 C.Soc.

119 Brussels 10 September 2004, Bank Fin.R. 2006, 25; Brussels 10 April 2003, Rev.Not.B. 2003, 676; Brussels 9 October 1984, RPS 1986, 50; Brussels 16 June 1981, RPS 1981, 145; O. Caprasse and M. Fyon, 'L'organisation du pouvoir dans les groupes de sociétés' in G.A. Dal (ed), Droit des groupes de sociétés. Questions pratiques (Larcier 2013) 185, 199, no 75; F. Magnus, Les groupes de sociétés et la protection des intérêts catégoriels (Larcier 2011) 58-62 and 82; O. Caprasse and R. Aydogdu, Les conflits entre actionnaires. Prévention et résolution (Larcier 2010) 17; E. Wymeersch, 'Hoofdlijnen van het Belgische recht van vennootschapsgroepen' (2008) Financial Law Institute Working Paper Series 2008-03, 12-13.

120 Cass. 4 February 1985, D 1985, 478 and JCP 1986, II, 20585. Confirmed in Cass. 2 July 1998, RSC 1999, 333; Cass. 4 September 1996, D 1996; Cass. 9 December 1991, Rev. Soc. 1992, 358; Cass. 13 April 1991, Rev.Soc. 1991, 785; Cass. 13 February 1989, Rev. Soc. 1989, 696 .

121 B. Bouloc, 'Droit pénal et groupes d'entreprises' (1998) Rev. Soc. 181, 197; A. François, Het vennootschapsbelang in het Belgische vennootschapsrecht (Intersentia 1999) 700701. 
shareholders could be held liable for discrepancies. However, courts are not in a position to punish such discrepancies: the offsetting 'advantages' are assumed in abstracto, but should not be demonstrated or proven in concreto. After all, the advantages may be merely implicit, contingent or intended. As this complicates judicial review too much, the Delaware Supreme Court held in Sinclair that setoff should only be allowed on specific transactions. ${ }^{122}$ By contrast, the inevitable result of Rozenblum is that courts defer to the discretion of corporate organs. ${ }^{123}$ For this reason, once again, corporate insiders - directors colluding with controlling shareholders - are only held liable if the transaction is manifestly unfair. ${ }^{124}$ Considering the lenient standard of review, a scholar claims that directors could rarely be found liable for illegal self-dealing. ${ }^{125}$ If the existence of a corporate group is established, the aforementioned liability grounds only prevent extremely unbalanced transactions, similar to the oneshot plundering of the company. ${ }^{126}$ The lenient standard of review discourages (minority) shareholders to sue directors. Case law on director liability suits brought by shareholders in a group context, is thus very limited. This is different for liability suits brought by creditors. This suggests that director liability does not offer much protection to outside investors against self-dealing in the examined jurisdictions.

14. The Netherlands: merits and limits of enquêterecht - While the derivative action is unavailable under Dutch company law, minority shareholders have a right to petition for the appointment of a committee of inquiry, called 'enquêterecht'. ${ }^{127}$ The Enterprise Chamber, a special division of the Amsterdam Court of Appeals, appoints such a committee if there is reasonable doubt that the company is mismanaged. Being entitled to access all books and records, the committee inquires into the policy and conduct of business of the company. The court - composed of both professional judges, academics and business persons - has the power to adopt 'appropriate measures', ranging from the nullification of transactions and the dismissal of directors to the dissolution of

122 Sinclair Oil v. Levien, 280 A.2d 717 (Del. 1971).

123 Eg Brussels 9 October 1984, RPS 1986, 50 (Court of Appeals) ("La décision de supporter la totalité des pertes résultant d'une opération et d'en décharger d'autres sociétés du même groupe avec lesquelles une association en participation avait été conclue, n'est pas manifestement contraire à l'intérêt social [...].").

124 Eg Cass. Cass. 30 september 2005, Arr. Cass. 2005, 1777 (bail without consideration).

125 T. Tilquin, 'La gouvernance d'entreprise et les groupes de sociétés' in Tendensen in het bedrijfsrecht - Intragroepsrelaties (Kluwer 2004) 75.

126 E. Wymeersch, 'Hoofdlijnen van het Belgische recht van vennootschapsgroepen' (2008) Financial Law Institute Working Paper Series 2008-03, 12.

127 Article 2:344 et seq NBW. 
the company. ${ }^{128}$ The Enterprise Chamber has considerable latitude in assessing, on the basis of the committee's report, whether a good policy is pursued by directors and shareholders. ${ }^{129}$

Within that margin of appreciation, the Enterprise Chamber has ruled that there is reasonable doubt about a company's mismanagement if a controlling shareholder "who makes a considerable part of the company's capital circulate within the group, does not provide adequate protection for the interests of the minority shareholders". ${ }^{130}$ Although the procedure does not constitute a remedy for minority shareholders to challenge specific transactions, it protects them to a certain extent against self-dealing. ${ }^{131}$ The procedure is intrusive and undesirable for directors and controlling shareholders, who thus have an incentive to refrain from behaviour that arouses suspicion. On the other hand, it has been observed that the case law of the Enterprise Chamber is not very consistent, which makes judgments unpredictable. ${ }^{132}$ The procedure is also quite radical, time-consuming and costly. ${ }^{133}$ The opening of an inquisitorial procedure is undesirable for minority shareholders too, because it immediately affects share price. Hence, if the enqueterecht is the only remedy to curb selfdealing, controlling shareholders may be underdeterred. Timmerman thus suggests that regardless of its merits, the procedure should be complemented with a specific, less ponderous mechanism for related party transactions. ${ }^{134}$

128 F. Veenstra, Impassezaken en verantwoordelijkbeden binnen bet enquêterecht (Kluwer 2010) 115-133.

129 J.H. Lestra and T. Salemink, 'Kroniek enquêterecht 2014' in M. Holtzer, A.F.J.A. Leijten and D.J. Oranje (eds), Geschriften vanwege de Vereniging Corporate Litigation 2014-2015 (Kluwer 2015) 28-29.

130 Hof Amsterdam 27 mei 1993, NJ 1993, no 723. Similarly: Hof Amsterdam 8 oktober 1998, NJ 1999, 348; Hof Amsterdam 3 november 2000, JOR 2001, 3; Hoge Raad 4 juni 199, NJ 1997, no 671.

131 F. Veenstra, 'Minderheidsaandeelhouders in opstand tegen tegenstrijdig belangtransacties: maar hoe?' (2013) WPNR 265.

132 H.J. De Kluiver, 'Over Delaware, de Ondernemingskamer en de aantrekkelijkheid van Nederland als vestigingsland' in Nederland, het Delaware van Europa? (Kluwer 2016) $143,146$.

133 M.J. Kroeze, Afgeleide schade en afgeleide actie (Kluwer 2004) 108-109.

134 L. Timmerman, 'Bescherming van minderheidsaandeelhouders tegen een meerderheidsaandeelhouder in een rechtsvergelijkend perspectief' in Nederlands ondernemingsrecht in grensoverschrijdend perspectief (Kluwer 2003) 88-90. 


\section{Unsatisfactory Approval Procedures}

15. France: 'majority-of-minority votes' are limited in scope and do not affect validity of transactions - A second legal strategy, besides judicial review, is to insulate the controlling shareholder from the decision-making process. While fairness review entails substantive fairness, approval procedures provide minority shareholders with procedural guarantees. Considering the weak protections of judicial review in the discussed jurisdictions, legislators have adopted specific approval procedures. First, French law requires boards to subject some contracts to the approval of the general meeting. ${ }^{135}$ These 'conventions contrôlées' include among other things contracts between the company and shareholders owning at least 10 per cent of the voting rights. ${ }^{136}$ The interested party is not entitled to vote, which constitutes an exception to the general rule (supra, no 10). The French procedure resembles 'majority-ofminority votes' as developed in common law jurisdictions. However, two weaknesses of this procedure should be pointed out. First, it does not apply to decisions which fall within the ambit of the general meeting. ${ }^{137}$ This is remarkable, considering that controlling shareholders may shuffle away substantial firm value through parent-subsidiary mergers.

Second, shareholder approval is not a condition for the validity of the transaction. French law does not require that related party transactions are concluded under the suspensive condition of shareholder approval. ${ }^{138}$ If shareholders subsequently reject an executed transaction, the transaction remains valid. ${ }^{139}$ If the company is damaged by a rejected transaction, the controlling shareholder or the directors could be held liable. This means that, in practice, majority-ofminority votes in France are merely a first step in a larger process, which ultimately relies on judicial review, where deferential standards are employed. This leads to underdeterrence of controlling shareholders. Moreover, nothing in the law suggests that the rejection by shareholders shifts the burden of proof to the defendants, as is the case in Delaware (supra, no 11). Finally, directors do not know how minority shareholders will assess a certain transaction, because such assessment relies on subjective valuation (infra, no 21). From an ex ante point of view, the contingency of erroneous rejection by the shareholders may overdeter directors.

137 C. Malecki, 'Conventions réglementées' in Répertoire de droit des sociétés (Dalloz 2002) no 37; M. Cozian, A. Viandier and F. Deboissy, Droit des sociétés (LexisNexis 2014) 352 .

138 This is the case in the United Kingdom: L.R. 11.1.1.

139 L.225-41 C.Com. 
16. Belgium: independent directors are not truly independent - Belgian law requires that transactions between a listed company and a controlling shareholder should be submitted to a committee of three independent directors, who draft a fairness report. ${ }^{140}$ This procedure is flawed for a couple of reasons. First, it only applies to transactions which fall within the ambit of the board. It provides no protection to minority shareholders for decisions which fall within the ambit of the general meeting, such as intra-group mergers. The Financial Services and Market Authority merely recommends that "the conflict of interest rules be applied voluntarily or "by analogy". ${ }^{141}$ Second, the fairness report is only a recommendation. The right to decide remains with the board. If the board does not follow the committee's recommendation, the minutes should elaborate on the reasons for the disagreement. Third, enforcement of the procedure is weak. If the board does not comply with the procedure, the transactions could be nullified. However, minority shareholders have no standing to sue. ${ }^{142}$ This is particularly odd, since the procedure aims at protecting minority shareholders. ${ }^{143}$

On a more fundamental level, it is questionable whether independent directors are truly independent from the controlling shareholder. ${ }^{144}$ Independent directors are an Anglo-American remedy for the lack of management monitoring by directors in the widely held company (supra, no 6). Hence, the criteria for 'director independence' relate to the absence of financial or operational ties between the independent directors on the one hand, and the company, management and CEO on the other hand. For instance, independent directors cannot be incumbent or former managers or employees of the company. To be sure, controlling shareholders and their affiliates often also disqualify for being an independent director. In Belgium, an independent director cannot be an employee, an executive, a family member or a representative of the controlling shareholder. ${ }^{145}$ However, the lack of board autonomy in controlled companies does not originate in financial or family ties between directors and controlling shareholders. By contrast, it originates in the 'carrots and sticks' that controlling

140 Article 524 C.Soc.

141 www.fsma.be/en/faq/5-are-conflict-interest-rules-intra-group-decisions-art-524companies-code-applicable-these

142 P. Ernst, Belangenconflicten in naamloze vennootschappen (Intersentia 1997) 986.

143 S. De Dier, Nietigheid van bestuursbesluit in een vennootschap (Roularta 2016) 242.

144 H. De Wulf, Taak en loyauteitsplicht van het bestuur in de nv (Intersentia 2002) 167; K. Geens, 'Helpt 'good corporate governance'? Over regels voor behoorlijk bestuur in vennootschappen' in P. D'Hoine and B. Pattyn (eds), Over grenzen en generaties heen (Leuven University Press 2012) 92.

145 Article 526ter C.Soc. 
shareholders hold over directors through their power to appoint directors, remove them and determine their salary (supra, no 6). Bebchuk and Hamdani thus claim: "Independent directors whose service on the board fully depends on the controller do not have adequate incentives to guard the interests of public investors in the face of controllers' conflicts." ${ }^{146}$ Moreover, revocability at will is a mandatory rule under Belgian law ${ }^{147}$, making directors even more dependent from controlling shareholders. ${ }^{148}$ None of this changes for independent directors. Accordingly, an OECD report on minority protection in Belgium questions whether independent directors "would really contradict the orders of a controlling company or shareholder on which they depend." 149 Saez and Guttierez suggest that the wrong use of independent directors in continental Europe is fostered by interests groups: by accepting independent directors in their companies, controlling shareholders managed to avoid stronger minority protection. ${ }^{150}$

\section{Conclusion: Need for Improvement}

17. Weak protections - The examined civil law jurisdictions offer rather weak protection to minority shareholders against related party transactions between the company and a controlling shareholder. In the three examined jurisdictions, courts generally defer to the discretion of corporate organs. General principles of law - good faith or the duty to act reasonably - only prevent extreme versions of value diversion. A recently adopted directive amending the Shareholders' Rights Directive (SRD) imposes several requirements on Mem-

146 L.A. Bebchuk and A. Hamdani, 'Independent Directors and Controlling Shareholders' (2017) 165 U.Pa.L.Rev. 1271, 1289.

147 Article 518, $\mathbb{\int} 3$ C.Soc. The Belgian Minister of Justice considered repealing this rule: $\mathrm{K}$. Geens, 'De sprong naar het recht voor morgen. Hercodificatie van de basiswetgeving' (2016) 73, available at www.koengeens.be. However, the draft bill of the new Belgian Code on Companies and Associations does not entirely repeal the rule. It merely provides that the bylaws can provide for a term of notice or a severance payment: Article art. 7:85, $\$ 3$ Wetsontwerp tot invoering van het Wetboek van vennootschappen en verenigingen en houdende diverse bepalingen, Parl.St. Kamer 20172018, nr. 3119/002.

148 S. Cools, 'Europe’s Ius Commune on Director Revocability' (2011) ECFR 199, 204.

149 OECD, 'Related Party Transactions and Minority Shareholder Rights' (2012) 58. Cf. L. Enriques, 'Related Party Transactions: Policy Options and Real-World Challenges (with a Critique of the European Commission Proposal) (2015) 16 EBOR 1, 18-19.

150 M. Gutiérrez and M. Sáez, 'Deconstructing Independent Directors' (2013) 13 JCLS 63, 75. 
ber States regarding related party transactions. ${ }^{151}$ The next chapter briefly discusses those requirements.

\section{Overview of Article 9c Shareholders' Rights Directive}

18. Amendment gives considerable leeway to Member States - First, Member States must ensure that related party transactions are publicly announced. ${ }^{152}$ Second, Member States must ensure that related party transactions are adopted according to procedures which prevent a related party from taking advantage of its position and provide adequate protection for the interests of the minority shareholders. ${ }^{153}$ The directive gives little indication as to the meaning of adequate protection. However, the directive explicitly states that Member States may allow conflicted shareholders to vote, if they ensure that the related party is prevented from approving the transaction despite the opposing opinion of the majority of shareholders who are not a related party, or a majority of independent directors. Put simply, related party transactions must be approved by either a majority of minority shareholders or (a committee of) independent directors. However, this requirement does not apply to 'clearly defined' shareholder decisions, provided that fair treatment of all shareholders is specifically addressed and adequately protected. ${ }^{154}$ Since this provision is an exception to the requirement of ex ante approval procedures, the requirement must mean that Member States may subject shareholder decisions involving a related party transaction to judicial review instead of $e x$ ante approval procedures.

In sum, unlike the European Commission initial proposal ${ }^{155}$, the directive gives considerable leeway to the Member States. They may subject related party transaction to a majority-or-minority vote, the approval of independent directors, or, for shareholder decisions, to judicial review. Each of these mechanisms complies with the directive from a legal point of view, provided that they offer adequate protection. The current legal strategies in Belgium, France and the Netherlands are flawed and cannot be considered to meet the latter require-

151 Directive (EU) 2017/828 of the European Parliament and of the Council of 17 May 2017 amending Directive 2007/36/EC as regards the encouragement of long-term shareholder engagement, Pb.L. 20.05.2017, 132/1.

152 Article 9c SRD, para 2-3.

153 Article 9c SRD, para 4.

154 Article 9c SRD, para 6, (b).

155 Proposal for a Directive of the European Parliament and the Council amending Directive 2007/36/EC as regards the encouragement of long-term shareholder engagement and Directive 2013/34/EU as regards certain elements of the corporate governance statement, $\operatorname{COM}(2014) 213$. 
ment. Hence, these jurisdictions must ensure that courts apply stricter standards of review to related party transactions, or subject these transactions to either majority-of-minority votes or the approval of directors which are truly independent from controlling shareholders.

The question remains which of these strategies is also efficient, i.e. achieving the lowest level of under- and overdeterrence. The next chapter elaborates on this question. First, it is discussed whether and under which circumstances, jurisdictions should choose judicial review over ex ante approval procedures and vice versa. Second, it is discussed whether and under which circumstances, related party transaction should be approved by independent directors rather than by (minority) shareholders and vice versa.

\section{Efficiency of Self-Dealing Mechanisms}

\section{A. Judicial Review or Approval Procedure?}

19. Judicial review and approval procedure are mutually exclusive - As legal strategies against self-dealing, judicial review and approval procedures strategies are mutually exclusive, because they rely on conflicting principles. Goshen explains that majority-of-minority votes constitute a property rule, while judicial fairness review constitutes a liability rule. ${ }^{156}$ Consider an agreement in which a controlling shareholder buys a certain asset from the company. Under an entire fairness review, a controlling shareholder is allowed to force the transaction upon the company, if he at least pays the price that the courts believe is fair. However, under majority-of-minority votes, outside investors are not obliged to approve such a transaction, even though terms and conditions would be considered fair by a court. Conversely, outside investors may approve of a transaction even if terms and conditions are unfair in a court's view.

If the market price is easily determinable, both rules lead to similar outcomes, assuming that all parties behave rationally and leaving aside transaction cost. On the other hand, if a market price is unavailable, courts should determine the subjective valuations of the transaction to both parties and find that any transaction between these two values is fair. This means, for instance, that when the asset is worth 80 to the company (seller) and 100 to the controlling shareholder (buyer), a price of 80 would be considered fair. If minority share-

156 Z. Goshen, 'The Efficiency of Controlling Corporate Self-Dealing: Theory Meets Reality' (2003) 91 Cal.L.Rev. 393, with reference to G. Calabresi and A.D. Douglas, 'Property Rules, Liability Rules, and Inalienability: One View of the Cathedral' (1972) 85 Harv.L.Rev. 1089. 
holders must approve the transactions, however, they may withhold their approval as long as a controlling shareholder does not pay what the asset is worth for him, although the offered price is more than what the asset is worth to the company. Majority-of-minority rules give minority shareholders bargaining power, enabling them to capture the transactional surplus. ${ }^{157}$ Legal rules shape the division of the transactional surplus differently: while judicial fairness favours controlling shareholders, approval procedures favour outside investors. Since the outcome of both strategies diverges, they cannot be applied to the same transactions. Fairness review thus renders approval procedures redundant and vice versa. Recent case law from the Delaware Chancery Court illustrates this: if an informed majority of minority shareholders approves the transaction, the standard of review shifts towards business judgment. ${ }^{158}$

20. Judicial fairness review is inexpensive if market price exists - If a related party transaction involves goods or services for which a market price exists, courts should have no difficulty in determining whether the transaction is fair or not. Their only task would be to determine whether the market is sufficiently thick and whether the market price equals the agreed price. The use of the judicial system is then inexpensive: the prospect of a judgment disapproving of the transaction would adequately deter controllers from value diversion through self-dealing, and minority shareholders would not actually have to file suit. It is then unnecessary - even undesirable - to require that the company additionally subjects these transactions to special approval procedures. It must simply be required that related party transactions are carried out at-arm'slength and that legal action by minority shareholders is not unduly burdened by procedural barriers.

All of this assumes that transactions are carried out on a stand-alone basis. In reality, intra-group transactions are often interconnected. Accordingly, a company or its shareholders may be willing to incur a loss on one transaction, if it is compensated by a profit on other transactions. This philosophy underlies the Rozenblum doctrine (supra, no 13). Hence, even if a transaction is not atarm's-length on a stand-alone basis, it may be fair to the minority shareholders in the overall balance. Controlling shareholders should thus have the option to trade goods and services at prices below or above market price, on the condition that it complies with the procedure of related party transactions for which no market price exists, which is discussed in the following paragraph.

21. Judicial fairness review is expensive if no market price exists - Some related party transactions involve goods or services for which a market price

157 Z. Goshen, 'The Efficiency of Controlling Corporate Self-Dealing: Theory Meets Reality' (2003) 91 Cal.L.Rev. 393, 412.

158 In re MFW Shareholders Litigations (67 A.3d 496 (Del. Ch. 2013). 
does not exist. After all, the purpose of vertical integration is generally the manufacturing and supply of commodities that are confined to one's business. ${ }^{159}$ Hence, group companies sometimes trade very specific goods and services, for which no thick market exists. Moreover, intra-group mergers or similar asset deals boil down to a (partial) sale of a company, the value of which is extremely subjective. ${ }^{160}$ Here, use of the judicial system to curb self-dealing is expensive. As observed, fairness means that the transaction is carried out at a price between the seller's subjective valuation and the buyer's subjective valuation. While courts may be able to determine the objective market price, they can only assess the parties' subjective valuations by estimation. Fairness review thus entails a risk of judicial error. This risk of error increases as courts become less specialized and well equipped.

The risk of error, in turn, creates legal uncertainty as to the validity of the transaction and the (non-)liability of directors. This has two pernicious side effects. First, when a transaction is fair, companies need to factor in the contingency that the court ultimately finds the transaction illegal. Moreover, if rescission suits are unavailable, directors and shareholders must pay damages, which means that they possibly need to pay a higher price than the goods or services are worth to them. Risk of judicial error thus deters controlling shareholders from concluding value-increasing transactions. Second, when a transaction is unfair, minority investors take into account the contingency that the court ultimately finds the transaction legal. Since minority shareholders often bear litigation cost if they lose, the risk of judicial error prevents minority shareholders from challenging value-decreasing transactions. This, in turn, leads to an underdeterrence of controlling shareholders. Considering the cost

159 B. Klein, R.G. Crawford and A. A. Alchain, 'Vertical Integration, Appropriable Rents, and the Competitive Contracting Process' (1978) 21 JLE 297 (when a certain asset is specialized to one of the user's other assets, a market transaction would expose contracting parties to opportunistic behavior, because a customer would be able to force the supplier of said asset to renegotiate, lower the price to the value of this asset to the best alternative user, and thus appropriate a substantial part of quasi rent. Hence, the risk of opportunistic behavior by contracting parties, and the inability of the law to remedy this inconvenience, raises the cost of the contracting mechanism and favors vertical integration and the expansion of the firm.)

160 cf. B. Black and R. Kraakman, 'A Self-Enforcing Model of Corporate Law' (1996) 109 Harv.L.Rev. 1912, 1957-1958 ("The market value of property shall mean a price at which a seller who is fully informed about the value of the property and is not obliged to sell the property would be willing to sell, and at which a buyer who is fully informed about the value of the property and is not obliged to buy the property would be willing to buy.") 
of judicial error, "courts recognize that after-the-fact litigation is a most imperfect device to evaluate corporate business decisions." 161

22. Approval procedures are preferable if no market price exists - To be sure, shareholders and directors err too. Minority shareholders or their representatives may accidentally approve value-decreasing transactions or disapprove value-increasing transactions. However, the risk of error is lower in corporate approval procedures than in judicial fairness review. While courts must estimate what the transaction is worth to both parties, approval procedures rely on the contracting mechanisms. A transaction will only come about if both parties - controlling shareholder on the one hand and minority shareholders on the other hand - believe that the transaction is fair, i.e. meets their subjective valuation of what is exchanged. Moreover, approval procedures do not entail legal uncertainty as to the validity of the transactions, which means that controlling shareholders are less deterred from concluding value-increasing transactions. Conversely, since the efficiency of the strategy does not depend on the inclination of minority shareholders to file suit, controlling shareholders are more deterred from concluding value-decreasing transactions. In sum, approval procedures are preferable over judicial review if no market price exists. This idea aligns with Black and Kraakman's concept of a 'self-enforcing model of corporate law': increasing the involvement of direct participants, such as shareholders, and minimizing reliance on official enforcement. $^{162}$

The preference for approval procedures does not render courts redundant in the realm of self-dealing. While judicial review relies on substantive fairness, approval procedures rely on procedural fairness. Hence, these procedures must contain guarantees that those who are involved in the decision making process are well informed, not factually hindered from participating in the deliberations, etc. The enforcement of these procedural guarantees is confined to courts. Minority shareholders should be able to file suit if the approval by shareholders or directors is not sound. The role of the courts is here relatively uncomplicated. ${ }^{163}$ Hence, reliance on courts does not entail the same adjudication cost as a fairness review.

161 Joy v. North, 692 F.2d 880 (2d Cir. 1982).

162 B. Black and R. Kraakman, 'A Self-Enforcing Model of Corporate Law' (1996) 109 Harv.L.Rev. 1912.

163 Z. Goshen, 'The Efficiency of Controlling Corporate Self-Dealing: Theory Meets Reality’ (2003) 91 Cal.L.Rev. 393, 417. 


\section{B. Shareholders or Directors?}

\section{Limits of Majority-of-Minority Votes}

23. Majority-of-minority votes entail (high) transaction cost - If approval procedures are desirable, the question arises as to which party should approve related party transactions. Inspired by the law of the United Kingdom and Delaware, France now subjects all material transactions with related parties to the approval of minority shareholders (supra, no 15). Requiring shareholder approval for all related party transaction relies on the idea that outside investors may be able to protect their own interests, while directors cannot be relied upon to protect them. After all, except for the United Kingdom (infra, no 25), no jurisdiction today requires that minority shareholders are represented in the board. However, shareholder approval boils down to an implicit, often virtual negotiation between majority and minority shareholders. Hence, it entails transaction cost. ${ }^{164}$

First, it is a widely recognized problem of corporate governance that minority shareholders are generally not interested in exercising their voting rights, because the cost of doing so exceeds the personal benefits. Moreover, shareholders who attend meetings are not necessarily informed about all proposed resolutions. ${ }^{165}$ Studying the materials requires time and effort. ${ }^{166}$ Self-dealing often involves numerous complex transactions between several subsidiaries of the listed company, most of which are difficult to understand for laymen. Moreover, outside shareholders have difficulty assessing the operational usefulness of transactions to the company. ${ }^{167}$ The collective action problem and information asymmetry enable a controlling shareholder to push value-decreasing transactions through the general meeting without much controversy. ${ }^{168}$ This affects the efficiency of majority-of-minority votes as a legal strategy for self-dealing. ${ }^{169}$ Institutional investors are generally thought to ease

164 S. Cools, De verdeling van beslissingsbevoegdheden tussen algemene vergadering en raad van bestuur in de NV (Roularta 2015) 83.

165 T.H. Höger, 'Corporate Groups' (2014) SAFE Working Paper 66, 33.

166 Z. Goshen, 'The Efficiency of Controlling Corporate Self-Dealing: Theory Meets Reality' (2003) 91 Cal.L.Rev. 393, 416.

167 C. Van der Elst, 'Empowering the Audit Committee and the Auditor in Related Party Transactions' (2016) ECGI Law Working Paper 318/2016, 20.

168 L. Enriques, 'Related Party Transactions: Policy Options and Real-World Challenges (with a Critique of the European Commission Proposal) (2015) 16 EBOR 1, 17 and 30; Z. Goshen, 'The Efficiency of Controlling Corporate Self-Dealing: Theory Meets Reality’ (2003) 91 Cal.L.Rev. 393, 413.

169 cf. L. Enriques, 'Related Party Transactions: Policy Options and Real-World Challenges (with a Critique of the European Commission Proposal) (2015) 16 EBOR 1, 16. 
the collective action problem. ${ }^{170}$ Institutional investors include hedge funds, pension funds, life insurance companies and the like. ${ }^{171}$ Those investors often own a larger equity stake in the company than retail investors. Because they derive larger profits from their investments, monitoring management (and controlling shareholders) may be worthwhile for them. ${ }^{172}$ Accordingly, the success of majority-of-minority votes largely depends on the activity of institutional investors. ${ }^{173}$ Institutional investors tend to be more actively engaged when financial markets are strong. If financial markets are weak, monitoring controlling shareholders is not a viable business. Furthermore, the law often prevents institutional investors from voting in order to prevent conflicts of interests. ${ }^{174}$

Second, decisions which normally fall within the ambit of the board of directors, must now be approved by the general meeting. Shareholders have less information and expertise than directors. This is the reason why most decisions generally fall within the ambit of the board of directors in the first place. Second, minority approval requirements impose administrative burdens on the company. Related party transactions are concluded at any time of the year, while shareholders generally only convene once a year. Either transactions must be delayed, or concluded under the suspensive condition of minority approval. This may discourage controllers from entering into value-increasing

The author provides four conditions for majority-of-minority votes to guarantee that only fair related party transactions are entered into, one of which is that "the MOM approval is the outcome of a well-informed decision-making process, following full disclosure of all material information about the RPT".

170 B.R. Cheffins, Company Law - Theory, Structure and Operation (Clarendon Press 1997) 63-64; Z. Goshen, 'The Efficiency of Controlling Corporate Self-Dealing: Theory Meets Reality' (2003) 91 Cal.L.Rev. 393, 415; M.J. Roe, 'The Institutions of Corporate Governance' in C. Ménard and M.M. Shirley (eds), Handbook of New Institutional Economics (Springer, Dordrecht 2005) 381. See for an example of shareholder activism in France: C. Monaco and C. Bughin, 'L'activisme des investisseurs institutionnels sur la gouvernance et le mode de gestion des entreprises. Le cas de Wendel au sein du groupe Saint-Gobain' (2011) 28 Gestion 2000, 27.

171 D.S. Boss, B.L. Connelly, R.E. Hoskisson and L. Tihany, 'Corporate Governance. Ownership Interests, Incentives, and Conflicts' in C. Ménard and M.M. Shirley (eds), Handbook of New Institutional Economics (Springer, Dordrecht 2005) 254.

172 M.J. Roe, Strong Managers, Weak Owners. The Political Roots of American Corporate Finance (Princeton University Press 1994) 11.

173 cf. K.J. Hopt, 'Comparative Corporate Governance: The State of the Art and International Regulation' (2011) 59 Am.J.Comp.L. 1, 48 ("Sharebolder codecision rights, in contrast, must be exercised in order to be effective.")

174 M. Blair, Ownership and Control. Rethinking Corporate Governance for the TwentyFirst Century (The Brookings Institution 1995) 145-172. 
related party transactions. ${ }^{175}$ In France, such suspensive condition is not required, but it impacts the efficiency of majority-of-minority votes (supra, no 15).

\section{Committee of Minority Directors as an Alternative}

24. Independent directors should become minority directors, appointed or nominated and removed by outside investors - Compared to majority-ofminority votes, a procedure within the board of directors or the supervisory board has lower transaction cost, because boards are better informed, convene more regularly and are not affected by the collective action. ${ }^{176}$ However, boards in controlled companies are fundamentally conflicted when approving related party transactions, considering the influence of controlling shareholders over the appointment, dismissal and remuneration of board members, whether they are considered independent or not (supra, no 6 and 16). Board approval of transactions between a company and its controlling shareholders only provides adequate protection if the board members who approve such transactions are accountable to those shareholders whose interest they are thought to protect, i.e. minority shareholders. ${ }^{177}$

Bebchuk and Hamdani correctly claim that accountability of independent directors to minority shareholders requires that minority shareholders have a say over the appointment and dismissal of these directors. ${ }^{178}$ In controlled companies, independent directors should be 'minority directors'. ${ }^{179}$ While minority directors are a common device for the protection of minority shareholders in closed companies (through cumulative voting procedures), they are rare in public companies. ${ }^{180}$ The only real alternative for majority-of-minority

175 B. Black and R. Kraakman, 'A Self-Enforcing Model of Corporate Law' (1996) 109 Harv.L.Rev. 1912, 1954.

176 S. Cools, 'The Dividing Line Between Shareholder Democracy and Board Autonomy: Inherent Conflicts of Interest as Normative Criterion' (2014) 2 ECFR 258, 272; B. Black and R. Kraakman, 'A Self-Enforcing Model of Corporate Law' (1996) 109 Harv.L.Rev. 1912, 1959.

177 B. Black and R. Kraakman, 'A Self-Enforcing Model of Corporate Law' (1996) 109 Harv.L.Rev. 1912, 1959.

178 M. Gutiérrez and M. Sáez, 'Deconstructing Independent Directors' (2013) 13 JCLS 63, 86.

179 L.A. Bebchuk and A. Hamdani, 'Independent Directors and Controlling Shareholders' (2017) 165 U.Pa.L.Rev. 1271, 1290-1293.

180 Minority directors are mandatory for controlled firms in Italy and Spain: M. Ventoruzzo, 'Empowering Shareholders in Directors' Elections: A Revolution in the Making' (2011) ECFR 105, 140-141. 
votes at board level, however, is the approval by a committee of minority directors. ${ }^{181}$ Such system of minority directors could be designed in several ways. ${ }^{182}$ Minority shareholders could have an exclusive right to either appoint minority directors or to nominate them. In most jurisdictions, directors are removable at will. This means that even when outside investors are empowered to elect their representatives, controlling shareholders could easily remove them. Minority shareholders should thus also have a veto right over the dismissal of minority directors. ${ }^{183}$ However, while veto rights prevent controlling shareholders from punishing directors for disloyalty, they do not guarantee that minority directors protect minority shareholders. ${ }^{184}$ In order to better align minority directors and outside investors, two options are available. First, minority shareholders could be granted an exclusive right to remove minority directors. Second, it could be provided that (minority) directors are up for reelection every (other) year.

The United Kingdom displays a tendency to insulate independent directors from the controlling shareholder. The U.K. Listing Rules require that independent directors are elected by both (the majority of) all shareholders, and (the majority of) all non-controlling shares. ${ }^{185}$ At first glance, this induces independent directors to actually foster the interests of minority shareholders, since they cannot be re-elected without their approval. However, the listing rules do not require the approval of minority shareholders for the dismissal of an independent director. In the United Kingdom, all directors are removable at will. This means that a controlling shareholder may punish directors for being too independent. On the other hand, minority shareholders do not have the power to remove independent directors before expiration of the period of office. This again, gives an edge to the controlling shareholder over the minority shareholder. Ideally, outside investors have similar rights over a directors' dismissal as they have over their election and re-election.

To be sure, if approval by minority shareholders of related party transactions is affected by the collective action problem, then so is the election of minority investors. However, one could expect these transaction costs to be lower. First, election of investors requires less technical information and research than related party transactions. Second, certain directors will specialize in the detection of self-dealing and the representation of minority shareholders. Reputa-

181 B. Black and R. Kraakman, ‘A Self-Enforcing Model of Corporate Law' (1996) 109 Harv.L.Rev. 1912, 1959.

182 L.A. Bebchuk and A. Hamdani, 'Independent Directors and Controlling Shareholders' (2017) 165 U.Pa.L.Rev. 1271, 1293-1295.

183 According to Kastiel, a similar arrangement is necessary for the executive compensation of minority directors: K. Kastiel, 'Executive Compensation in Controlled Companies’ (2015) 90 Ind.L.J. 1131, 1172.

184 cf. The lack of incentives of independent directors in the widely held firm to improve shareholder wealth of independent directors in the widely held firm: L.A. Bebchuk and J. Fried, Pay without Performance (Harvard U. Press 2004) 206.

185 L.R. 9.2.2B. 
tion and managerial markets could then help investors to select their representatives. ${ }^{186}$ While 'regular' directors are selected on the basis of their ability to manage the company within a certain sector, minority directors should be selected on the basis of their ability to detect self-dealing and to evaluate the fairness of such transactions.

The role of minority directors is the approval (or disapproval) of transactions between the company and the controlling shareholder. ${ }^{187}$ The presence of minority directors should not interfere with the controller's ability to manage the company. ${ }^{188}$ This has two major implications. First, the number of minority directors should be limited. In order to avoid deadlock inside the committee, an odd number is preferred. Second, minority directors should not have special power outside the context of self-dealing. However, they should not be external experts who assess transactions from a purely financial point of view. By contrast, minority directors should be fully-informed members of the board, who deliberate on other decisions too, but without special powers. ${ }^{189}$

\section{Balancing Both Procedures}

25. Intervention of independent directors is not desirable upon game-ending decisions - A last question is how the intermediation of minority directors relates to the general meeting for transactions which fall within its powers. In the context of self-dealing, this hypothesis is mostly confined to intra-group mergers or equivalent transactions. In some jurisdictions, sale of substantial assets requires shareholder approval too. As discussed, shareholder approval in controlled companies is trivial, since the controlling shareholder holds enough voting rights to have a transaction approved. One option is to require approval by the minority directors on board level. Today, boards play an important role in such transactions, because they enter into negotiations and draft the corporate ballot. Another option is to require shareholder approval through a majority-of-minority vote. The advantages and drawbacks of both procedures have been discussed previously in this section.

186 M. Gutiérrez and M. Sáez, 'Deconstructing Independent Directors' (2013) 13 JCLS 63, 93.

187 L.A. Bebchuk and A. Hamdani, 'Independent Directors and Controlling Shareholders' (2017) 165 U.Pa.L.Rev. 1271, 1306-1307; M. Gutiérrez and M. Sáez, 'Deconstructing Independent Directors' (2013) 13 JCLS 63, 93.

188 L.A. Bebchuk and A. Hamdani, 'Independent Directors and Controlling Shareholders' (2017) 165 U.Pa.L.Rev. 1271, 1308.

189 M. Gutiérrez and M. Sáez, 'Deconstructing Independent Directors' (2013) 13 JCLS 63, 93. 
However, shareholder resolutions sometimes raise an additional issue. In some cases, the related party transaction causes the disappearance of the company, which means that the minority directors lose their jobs. Hence, they have an incentive to reject transactions, even if they are fair to the outside investors. On the other hand, the collective action problem is smaller for this type of transactions than for day-to-day business transactions, since they have a direct impact on the shares. Consistent with Cools' framework of distribution of powers ${ }^{190}$, a distinction could be made. If a transaction, falling within the ambit of the general meeting, causes the disappearance of the company, majority-of-minority votes are desirable over minority directors' approval. If a similar transaction does not cause the disappearance of the company, the transaction could find approval by either a majority of minority shareholders, or a committee of minority directors, the desirability of which is determined by the level of activism of institutional investors (supra, no 23).

\section{Conclusion}

26. The law of Belgium, France and the Netherlands does not offer adequate protection to minority shareholders against related party transaction, while general principles of company law also do not constrain controlling shareholders. In light of Article 9c SRD, this paper presents some starting points for improving minority protection against related party transactions. First, it is argued that approval procedures for related party transactions are generally preferable over judicial review. Judicial review is expensive, especially when courts are not specialized or well-equipped to deal with financial transactions. Second, it is argued that 'majority-of-minority' votes do not always have the desired effect, because shareholder voting is affected by the collective action problem. As a workable alternative, it is suggested that jurisdictions subject most related party transactions to the approval of a committee of minority directors which cannot be appointed and/or removed by the controlling shareholder only.

190 S. Cools, 'The Dividing Line Between Shareholder Democracy and Board Autonomy: Inherent Conflicts of Interest as Normative Criterion' (2014) 2 ECFR 258. 